\section{All-Bukhāin}

Jurnal Ilmu Hadis
Vol. 2 No. 2, Desember 2019

E-ISSN 2622-7606, P-ISSN 2622-7606

https://journal.iainlangsa.ac.id/index.php /bukhari/index

\title{
الإشكاليات في حديث "الشؤم في ثلاث؛ المرأة والدّار والفرس" وحلولها
}

\author{
Nurul Badriyah binti Ali \\ Ph.D candidate, Department of Quran and Sunnah, Kulliyah of Islamic Revealed \\ Knowledge and Heritage, International Islamic University Malaysia (IIUM) \\ Jalan Gombak, 53100, Gombak, Selangor, Malaysia \\ Email: badriyah1089@gmail.com
}

DOI: http:dx.doi.org/10.32505/al-bukhārī.v2i2.1222

Submitted: 2019-11-04 | Revised: 2019-12-04 | Accepted: 2019-12-21

\begin{abstract}
Abstrak
Ada beberapa hadis șahīh yang perlu dijelaskan karena memiliki makna yang janggal atau musykil menurut pandangan sebagian orang. Hal ini bisa jadi diakibatkan oleh minimnya pemahaman terhadap makna hakiki yang dikandung oleh hadis tersebut atau adanya sangkaan tidak baik terhadap hadis tersebut. Hal ini memungkinkan terjadinya hinaan terhadap hadis nabawiyah khususnya pada mereka yang mengingkari sunnah dan tidak beriman kepada Allah. Salah satu contoh hadis musykil ini adalah hadis "alSyu 'üm fi Tsalās̀”. Oleh karena itu artikel ini akan membahas segala persoalan yang berkaitan dengan hadis ini. Seperti pada zahirnya hadis ini bertentangan dengan aqidah islamiyah dan beberapa hadis yang lain. Bahkan, disebutkan bahwa Aisyah RA menolak adanya hadis ini. Hadis ini juga didakwa telah dimansukhkan oleh ayat al-Quran dan hadis-hadis șah̄ịh yang lain, juga, ungkapan buruk kepada Șaḥịh al-Bukhārī karena memuat hadis ini. Artikel ini menggunakan metode analitis dan induktif yang menghasilkan kesimpulan bahwa kalimat al-Syu ūm yang tersebut di hadis berikut bukanlah kesialan yang diharamkan. Dan tiga hal yang disebutkan dalam hadis ini dikarenakan teramat sering dilakukan oleh orang banyak. Dan tiga hal yang disebutkan ini memiliki makna khusus. Perkataan Aisyah bahwa Abu Hurairah itu berbohong adalah karena terlalu marah. Dan para Ulama juga menetapkan bahwa hadis ini tidak mansukh oleh ayat al-Quran atau hadis-hadis lainnya. Maka hadis ini tetap memiliki derajat yang sahīh dengan makna khusus yang dimilikinya.
\end{abstract}

Kata Kunci : Masalah, Penyelesaian, Hadis, Sial 


\section{ملخّص}

هناك الأحاديث الصحيحة التّي تحتاج إلى بيان مفاهيمها لأنها تشكّل بعض الإشكاليات في نظر بعض الناس، إمّا من جهالتهم بمفهومها الحقيقي أو من سوء ظنّهم إليها، وذلك قد يكون محال للطعن في الني السنّة والأحاديث النّبوية، وخصوصًا عند منكري السنّة والمشركين بالله. ومن أمثلة هذه الأحاديث: حديث "الشؤم في ثلاث". ولهذا، يتحدّث هذا البحث عن الإشكاليات التّي تتعلّق بهذا الحديث، وحنّا

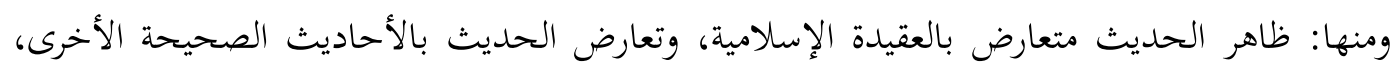
والادّعاء برفض عائشة هذا الحديث، والقول أنّ الحديث منسوخ بالآية والأحاديث الصحيحة الأخرى، والطعن في صحيح البخاري لحمل الحديث يشتمل على شرك صريح. ويستخدم البحث المنهج

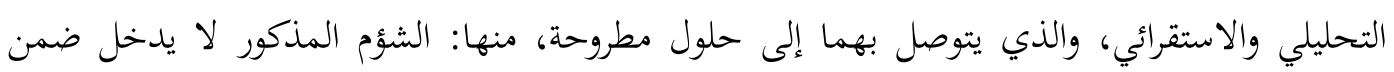
الطيرة المحرّمة، والأمور الثلاثة مِن أكثر ما يتطير بها الإنسان لطول ملازمتها، والشؤم في الثلاثة جاء

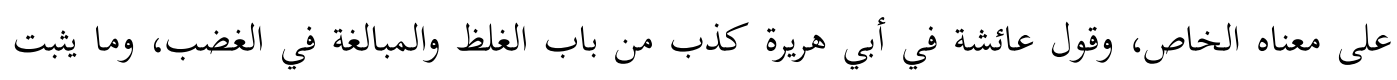
من خلال تأويل العلماء أنّ هذا الحديث منسوخ بالآيات القرآنية أو الأحاديث الصحيحة الأخرى، فيبقى على صحمّته مع الحمل بالمعنى الخاص له.

الكلمات المفتاحية: إشكالية، حلول، الحديث، الشؤم 
ويتبيّن لنا أنّ الأمور الثّلاثة التي تقصد

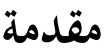

بها الأحاديث هي: المرأة، والفرس، والدّار.

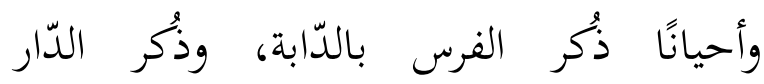
بالمسكن. أمّا لفظ المرأة فذكُر بلفظٍ واحدٍ في واحِّ جميع الأحاديث. وكلّ هذه الأحاديث رواها كثيرًا عن ابن عمر، كما كان هناك مِن رواية

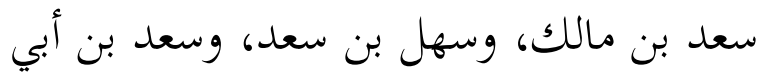

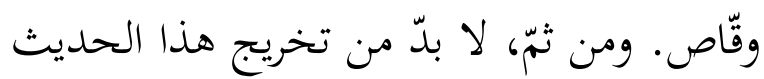
من أجل بيان طرقها حتى لا يكون فيه ريب أنّه من الصحّاح. وذلك كما يلي: تخريج الحديث. ورد هذا الحديث كثيرة طرقها ومتنوعة ألفاظها، وذلك من خلال أربع روايات كما ذكرناها، ولكلّ روايات طرقها المعينة:

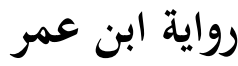
روى الإمام البخاري هذا الحديث أكثر من مرّة بطرق متعدّدة، منها: أولًاًا: رواية أبي اليمان عن الِّان شعيب عن الزهري عن سالم بن عبد الله عن

د.ط، د.م: مؤسسة الرسالة، ط1، 1416هـ/ 1996م، مسند



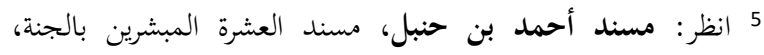

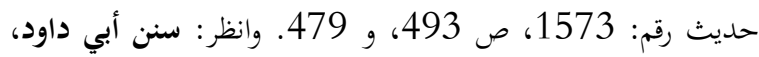
كتاب الطب، باب في الطيرة، التحفة 24، حديث رقم
إنّ هذا الحديث جاء بألفاظ عديدة، منها: \} الشؤم في المرأة، والدّار، والفرس\{ 1)، وهناك زيادة لفظ \} إنّما الشؤم في ثلاثة حديث آخر 2 وبزيادة لفظ ك إن كان الشؤم في شيء ففي الدّار والمرأة والفرسج في حئ حديث

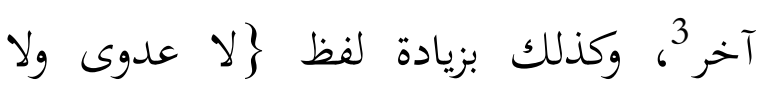
طيرة، والشؤم في ثلاث

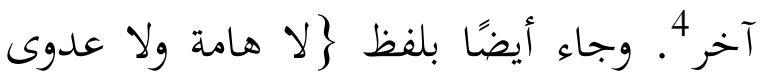
ولا طيرة إن يكن ففي المرأة والفرس والدار جُ5 ك. 1 انظر: البخاري، صحيح البخاري، د.ط، تخريج وضبط: صدقي

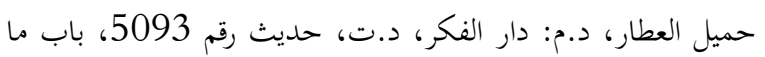

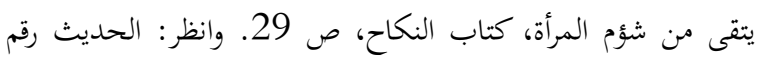
2099

2 انظر: البخاري، صحيح البخاري، حديث رقم 2858، باب ما

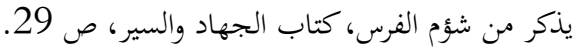

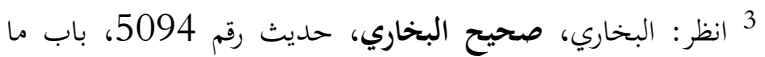

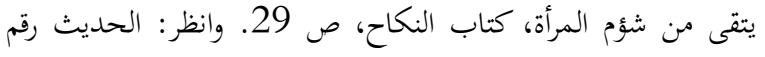

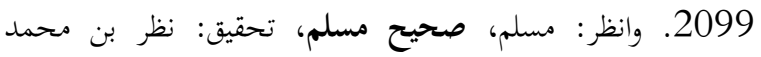

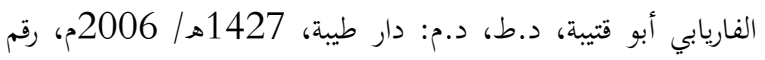

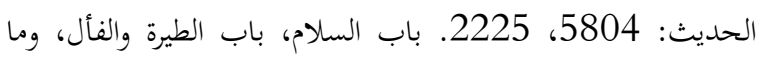
يكون فيه الشؤم، كتاب الطب، ص 987. وانظر: أبو داود سليمان

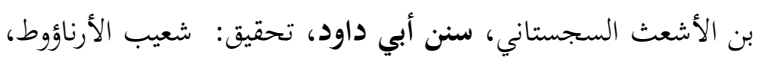

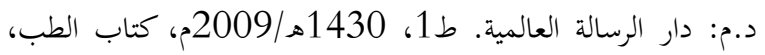

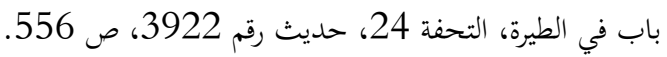

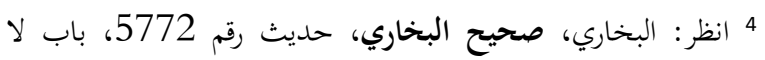

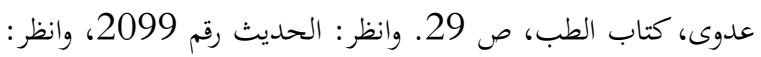
أحمد بن حنبل، مسند أحمد بن حنبل، تحقيق: شعيب الأرناؤوط، 
عمر عن يونس عن الزهري عن ابن عمر 11. سادسًا: عن عبد الله بن مسلمة بن قعنب عن مالك بن أنس عن ابن شهاب، عن حمزة وسالم، عن عبد الله بن عمر 12.

والأحاديث التي رواها الإمام مسلم

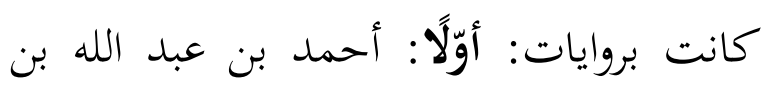

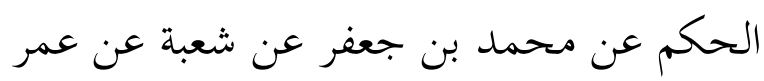
بن محمد بن زيد عن ابن عمر 13. ثانيًا: رواية هارون بن عبد الله عن روح بن عبادة عن شعبة14. ثالثًا: رواية أبي بكر بن إسحاق عن لن

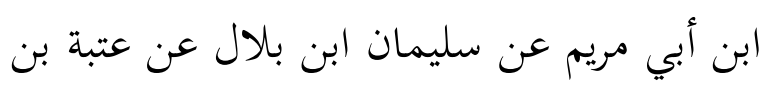
مسلم عن حمزة بن عبد الله بن عمر 15 ــابعًا: رواية عبد الله بن مسلمة بن قعنب عن مالك بن بن بن

11 انظر: البخاري، صحيح البخاري، كتاب الطب، باب الطيرة،

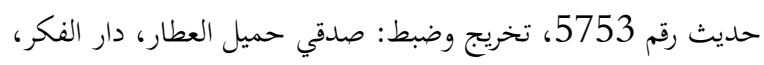

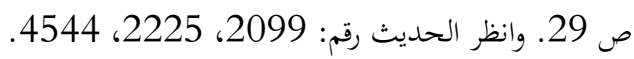

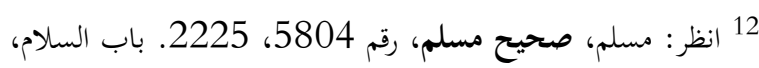

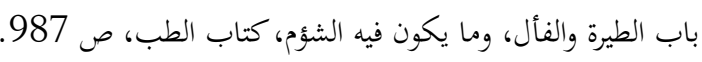
13 انظر: مسلم، صحيح مسلم، رقم 5807. باب الفال، وما بكون فيه الشوم كناب الطب، صام، كتاب الطب، ص 14. 14 انظر: مسلم، صحيح مسلم، رقم 5808، كتاب الطب، ص 1589 15 انظر: مسلم، صحيح مسلم، رقم 5809 صلم، باب السلام، كتاب الطب، ص
عبد الله بن عمر ك. ثانيًا: عن إسماعيل عن مالك عن ابن شهاب عن حمزة وسالم ابني عبد الله بن عمر عن عبد الله بن عمر ·. ثالثًا: رواية محمد بن منهال عن يزيد بن زريع عن عمر بن محمد العسقلاني عن أبيه، عن ابن عمر هـ رابعًا: عن عبد الله بن مسلمة عن مالك عن أبي حازم بن دينار عن سهل بن سعد الساعدي 9. خامسًا: عن سعيد بن عفير عن ابن وهب، عن يونس، عن ابن شهاب عن سالم بن عبد الله وحمزة عن ابن عمر 10. سادسًا: عن عبد الله بن محمد عن عثمان بن

6 انظر: البخاري، صحيح البخاري، حديث رقم 2858، باب ما

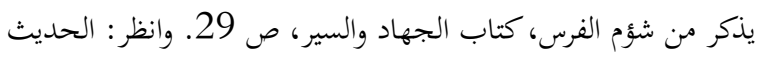
رقم 2099. 7 انظر: البخاري، صحيح البخاري، حديث رقم 5093، باب ما

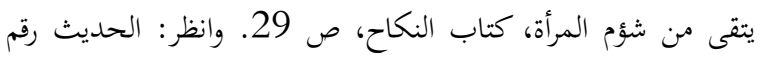
2099

8 انظر: البخاري، صحيح البخاري، حديث رقم 5094، باب ما يتقى من شؤم المرأة، كتاب النكاح، ص 29 20. وانظاري، حلـيث رفم : الحديث رقم 2099 9 انظر: البخاري، صحيح البخاري، حديث رقم 2859، باب ما

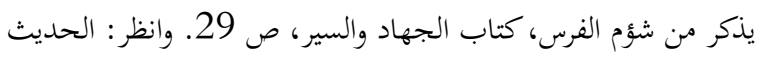
رقم 2858 و 2095. 10 انظر: البخاري، صحيح البخاري، حديث رقم

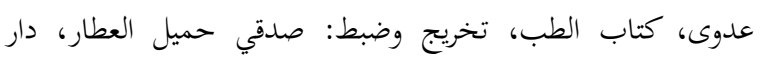
الفكر، ص 29. وانظر : الحديث رقم 2099. 
أمّا الأحاديث عن طريقة سهل بن سعد كانت بثلاثة روايات: أولَاًا: رواية عبد الله بن مسلمة بن قعنب عن مالك عن أبي حازم، عن سهل بن سعد 21. ثانيًا: رواية أبي بكر بن أبي أبي شيبة

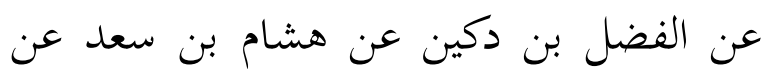
أبي حازم، عن سهل بن سعد 22. ثالثًا: رواية عبد الله بن يوسف عن مالك، عن أبي حازم،

$$
\text { عن سهل بن سعد } 23 .
$$

\section{حديث سعد بن أبي وقاص}

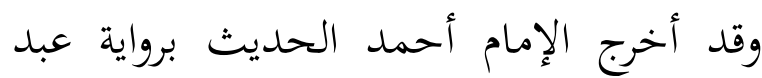

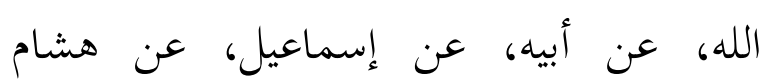
الدستوائي عن يحي بن أبي كثير الحضرمي بن

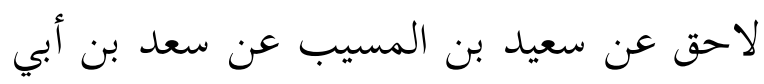
وقاص عن الطيرة224.

وبهذا، يتبيّن لنا من خلال الطرق الّيتي ذكرناها سابقًا أنّ هذا الحديث بين جاء من طرق متعدّدة، وكثيرها في كتب صحّاح للإمامين:

21 انظر: مسلم، صحيح مسلم، رقم 5810، 2226.

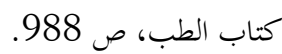

22 انظر: مسلم، صحيح مسلم، رقم 5811، صناب، صاب السلام، كتاب الطب، ص 988.

23 انظر: البخاري، صحيح البخاري، حديث رقم 5095، باب ما

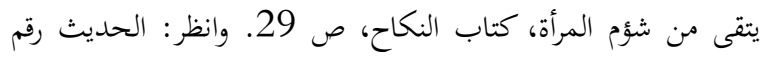
.2859

24 انظر: أحمد بن حنبل، مسند أحمد بن حنبل، مسند العشرة المبشرين بالجنة، حديث رقم 1573، ص
بن أنس عن يحي بن يحي عن ابن شهاب عن حمزة وسالم عن عبد الله بن عمر 16. أمّا الأحاديث التي أخرجها أبو داود في سننه عن ابن عمر فهي بروايات: القعنبي عن مالك عن ابن شهاب، عن حمزة وسالم،

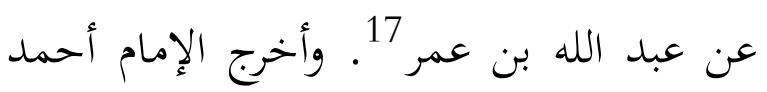
في مسنده عن طريق عثمان بن عمر عن يونس عن الزهري عن سالم عن ابن عمر 18. حديث سعد بن مالك أخرج الإمام أبو داود الحديث في سننه عن

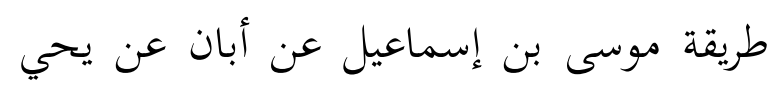
عن الخضرمي بن لاحق عن سعد بن المسيب،

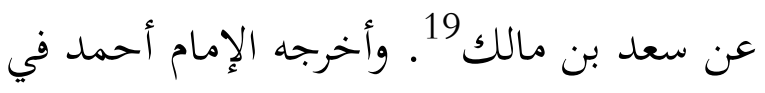
مسنده عن سعيد بن المسيب عن سعد بن

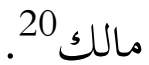
حديث سهل بن سعد 16 انظر : مسلم، صحيح مسلم، رقم 5804، 2225. باب السلام،

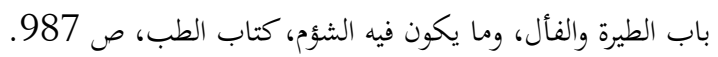

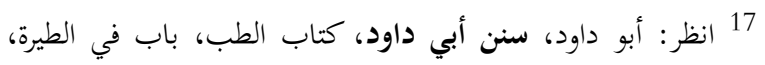

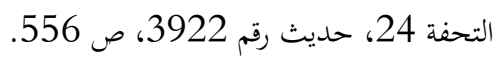

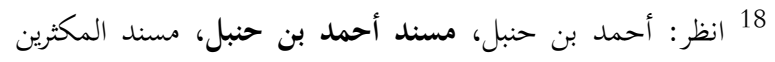

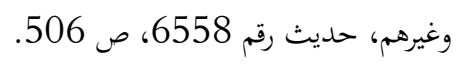

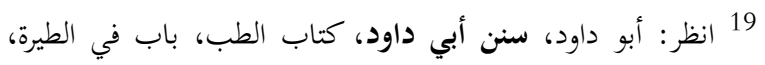

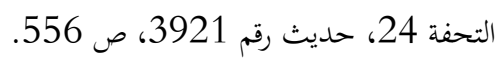
20 انظر: أحمد بن حنبل، مسند أحمد بن حند حنبل، مسن مسند العشرة

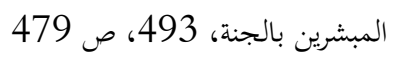


ينتف، ولإيمان العرب بالطيرة، عقدوا الرتائم

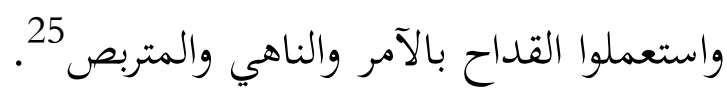
وقال القاضي عياض ذكر الحديث

الأمور الثلاثة لأنّها كانت ممّا يتقى من الشؤم فيها، "ومعناه: ما كانت عادة الجاهلية تتطير به. وقيل: معنى الحديث: إن كان في شيء ففي هذه الثّاثل. وقيل: معناه إنّ النّاس يعتقدون ذلك فيها"26. وذكر أبو داود بقول هيل الإمام مالك عن الحديث: كم من دار سكنها قوم فهلكوا ثم سكنها آخرون فهلكوا فهذا

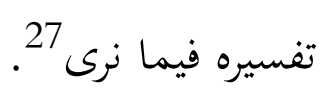

وإضافة على ذلك، ذكر الشيخ علي

الصعيدي أنّ الشؤم إن كان له حكم ثابت، ففي ثلاثة أشياء: المسكن والمرأة والفرس؛ وبيّن الشؤم في تلك الأمور: شؤم المسكن هو

25 انظر: القرطبي، التمهيد لما في الموطأ من المعاني والأسانيد،

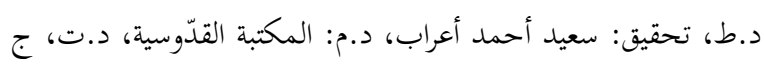
9، ص 282-283.

26 القاضي عياض المالكي، مشارق الأنوار على صحاح الآثار في شرح غريب الحديث، الموطأ والبخاري ومسلم، تحقيق: إبراهيم

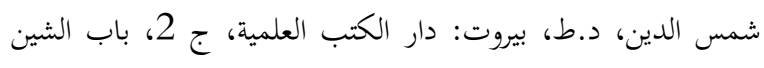

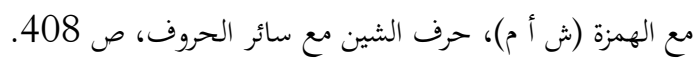

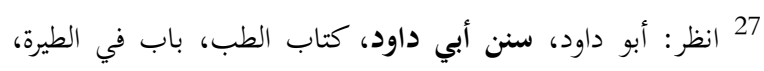
التحفة 24، التعليق لحديث رقم 3922، ص داود، داود، كناب الطب، باب
البخاري ومسلم، وكذلك في سنن أبي داود

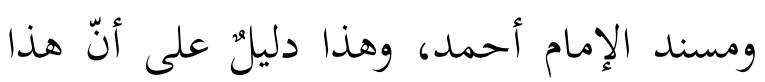

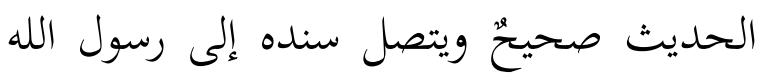

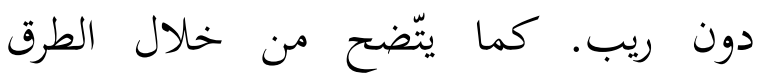

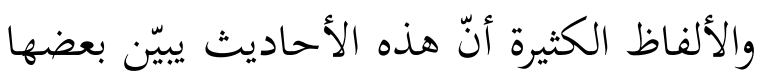

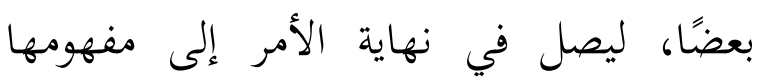

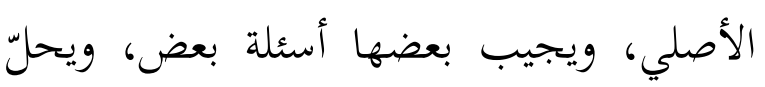
من خلال بعض إشكالية بعضها آخر، ونبدأ ذلك بيان مفهومه الإجمالي. مفهوم إجمالي للحديث إنّ الشؤم بمعنى الطيرة، وهو من عمل التطمي لـعليث

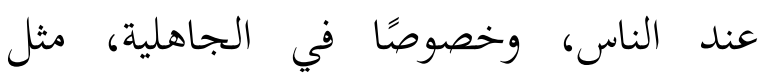
استعمالهم الحيوانات كالغراب لتعيين أفعالهم

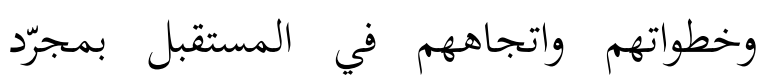
الإيمان بها. وذلك كما ذكر القرطبي أنّ أصل فئل فئل

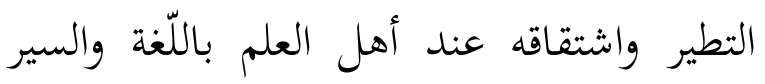
والأخبار، هو مأخوذ من زجر الطير ومروره سانحا أو بارحا. منه اشتقوا التطير، ثم استعملوا ذلك في كل شيء من الحيوان وغير الحيوان،

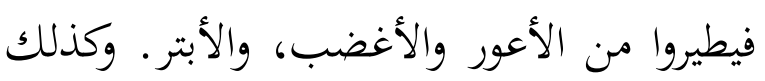
إذا رأوا الغراب أو غيره من الطير والاعضي، ولابتر وكنلى أولى 
تلحق أصحابك، والدار تكون ضيقة قليلة المرافق \{ وللطبراني من حديث أسماء \} إنّ من شقاء المرء في الدنيا سوء الدّار والمرأة والدّابة وفيه سوء الدار ضيق ساحتها وخبث جيرانها، وسوء الدابة منعها ظهرها وسوء طبعها، وسوء

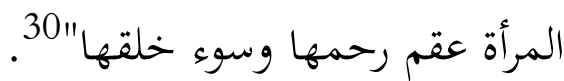
ونخلص من البيانات السابقة أنّ الشؤم هو الطيرة، وهو في أصله عمل محرّم في الإسلام، ولكنّ الشؤم المذكور في الحديث من وني خلال الأمور الثلاثة هو علامةٌ لما يتطيّر بها كثير من النّاس، وكذلك يعتقدون بعض النّاس أنّ الشؤم إن كان في شيء انغاء في ودي هذه الأمور. ونفهم أيضًا من خلال شروح وتفاسير العلماء السابقة أنّ كلمة الشؤم في الثلاثة تأتي بمعنى

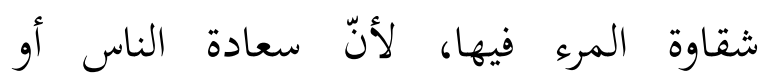
شقاوتهم تتعلّق بهذه الأمور الثّلاثة. والله أعلم. التحديات التي واجهها هذا الحديث قد اتّضح لنا مفهوم الحديث الإجمالي من خلال شروح العلماء وتفاسيرهم وبيانهم، إلّا أنّه

30 الحافظ ابن حجر العسقلاني، فتح الباري شح صحيح البخاري،

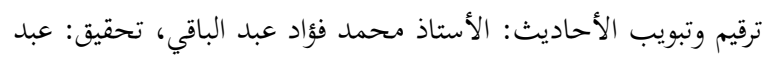

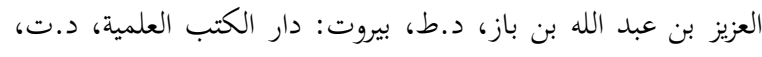

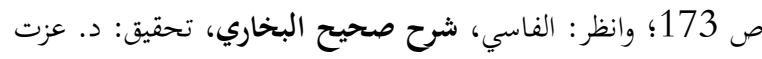

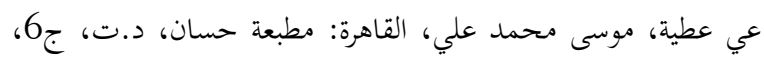

سوء الجيران، وشؤم المرأة هو قلة نسلها وسوء خلقها، وشؤم الفرس ترك الغزو عليه 28.

وسئل عن حديث محمد بن سعل عن

سعد عن النبي فقال: \{ثلاث من السعادة وثلاث من الشقاوة فذكر المرأة والدار

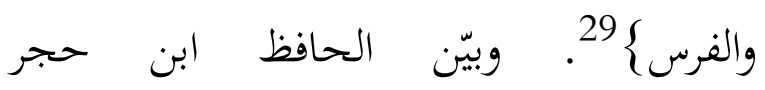

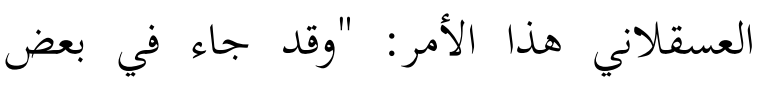
الأحاديث ما لعله يفسر ذلك وهو ما أخرجه

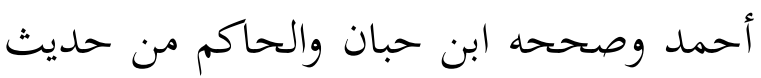
سعد مرفوعا: \}من سعادة ابن آدم ثلاثة: المرأة الصالحة، والمسكن الصالح، والمركب الصالح.

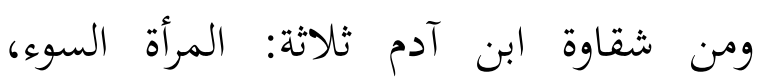

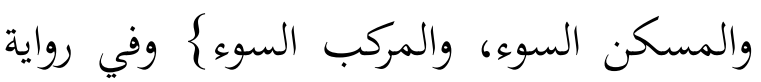

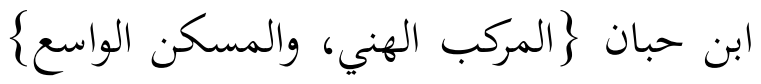
وفي رواية للحاكم جوثلاثة من الشقاء: المرأة تراها فتسوءك وتحمل لسانها عليك، والدّابة تكون قطوفا فإن ضربتها أتعبتك وإن تركتها لم علميك

28 انظر: الصعيدي، الشيخ علي الصعيدي العدوى المالكي، حاشية على كفاية الطالب الرباني لرسالة ابن أبي زيد القيرواني، الهامش:

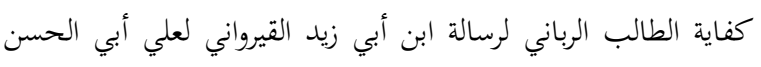

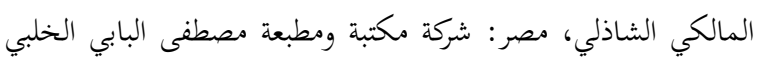

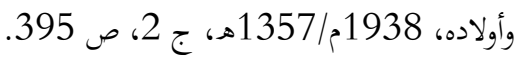
29 أخرجه الطبراني في معجمه الكبير، نقلا عن الدارقطني، العلل

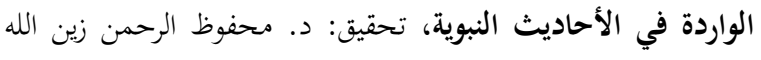

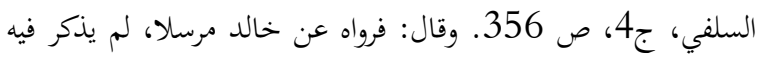

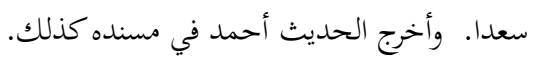


سادسًا: إنّ الحديث منسوخ باللآيات القرآنية والأحاديث الصحيحة الأخرى، وذلك بلك

بسبب الرفض والتعارض التي ذكرناه سابقًا. وعلى هذا الأساس، قسّمت الباحثة الإشكاليات إلى خمسة؛ الإشكالية الأولى: ظاهر الحديث متعارض بالعقيدة الإسلامية، والإشكالية الثانية: الحديث متعارض بالأحاديث الصحيحة الأخرى، والإشكالية الثالية: رفض عائشة الحديث، والإشكالية الرابعة: الحديث منسوخ بالآيات والأحاديث الصحيحة الأخرى، الإشكالية الخامسة: الطعن في صحيح البخاري لحمل الحديث يشتمل على شرك صريح. ومستعينًا بأقوال العلماء السابقين، قامت الباحثة بمحاولة البحث عن بكرئ الحلول لهذه الإشكاليات. إن شاء الله.

الإشكالية الأولى: ظاهر الحديث متعارض بالعقيدة الإسلامية

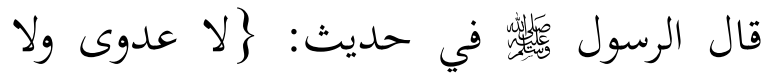
طيرة)، وذلك دليلٌ على أنّ الطيرة محرّم في الإسلام. ولكن هناك من يرى أن حديث

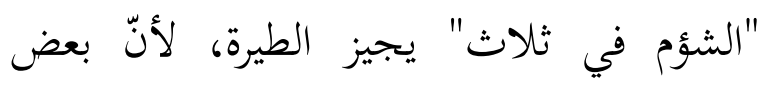

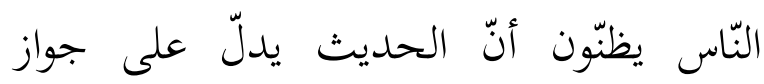
الطيرة، منها قوله: \} الشؤم في ثلاث في المرأة
قد يؤدي إلى مقصود باطل غير قصده الأصلي عند بعض النّاس بجهالتهم، ومنها؛ أوّلًاً: إنّ الطيرة في الإسلام جائزة لكون ثبوت الشؤم في ثلاثة الأمور المذكورة في الحديث؛ المرأة والدّار والفرس.

ثانيًا: من المعلوم أنّ الطيرة في الإسلام

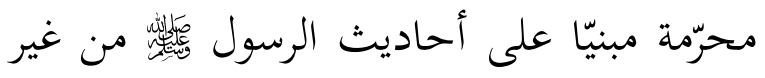
هذا الحديث، ولذلك يرى بعض النّاس أنّ هذا الحديث تخالف الأحاديث الصحيحة

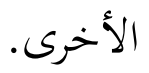

ثالثًا: هناك من يرى أنّ هذا الحديث متعارضٌ للعقيدة لأنّ الطيرة في حقيقتها تخالف عقيدة المؤمن. رابعًا: وهذه المعارضة بين ظاهر الحديث والعقيدة قد تكون محال لإنكار صحة مجموعة الصّحاح أو السنن أو المساند، وخصوصًا صحيح البخاري ومسلم لأنّ هذا الحديث مذكور فيهما أكثر من مرّة. خامسًا: هناك الاستشهاد من عائشة أنها قد رفضت هذا الحديث، وهذا محال لرفض صحّة هذا الحديث. 
تزعم العرب في الجاهلية، فأكذبهم الشرع"33. وهذا الكلام تشير أنّ الطيرة محرّم في الإسلام وشرك بالله، ومن ثمّ، يتسأل بعض النّاس عن الشؤم الذي ذكره الرسول في الحديث وكان يحصره في ثلاثة.

وإضافة إلى ذلك، قد عرّف الشيخ العيني أنّ الطيرة والشؤم بنفس المعنى فيقول الشؤم والطيرة واحد، والطيرة شرك. وزاد من بعده: والدّليل على أنّ الطيرة والشؤم واحد، ولهيرة قوله: جلا عدوى ولا طيرة وإن كان في شيء ففي المرأة والفرس والدار ج الحديث. وذهب العيني إلى بيان حديث آخر يشير إلى أنبّ الطيرة شرك. ج الطيرة شرك الطيرة شرك، ثلاثا، وما منا إلا وفيه، ولكن الله، عز وجل، يذهبه

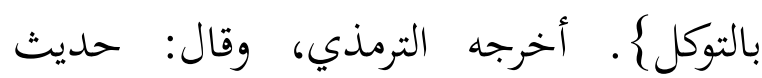

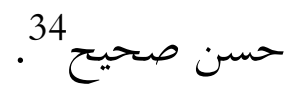

وبيّن أيضًا الشيخ كامل عويضة: "والتشاؤم من طبائع النفوس يقل ويكثر، وأهم علاج له التوكل على الله عز وجل كما في قول ابن مسعود: "وما منا إلا (أي: إلا يقع في

33 الدكتور وهبة الزحيلي، فتاوى معاصرة، ط1، دمشق: دار الفكر:

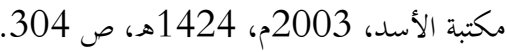

34 انظر: العيني، عمدة القارئ شح صحيح البخاري، تحقيق: عبد

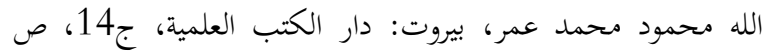

والدابة والداري\{ وفي رواية \}لا عدوى ولا طيرة، والشؤم في ثلاث \{ الحديث 31.

وهناك السؤال في تيسير العزيز الحميد في شرح كتاب التوحيد، "هل الطيرة شرك بالله؟ والجواب: نعم، لأن الطيرة تشاؤم، قال تعالى:

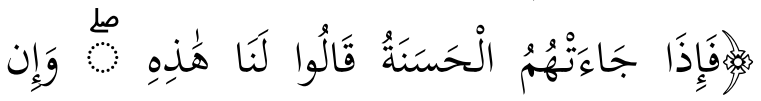

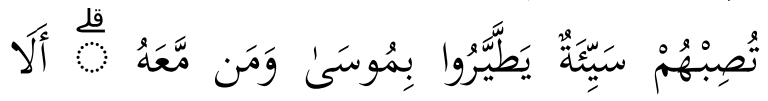

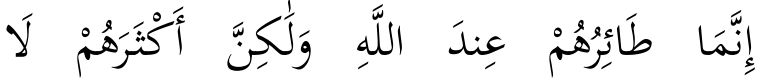
يَعْلَمُونَهُه.] [سورة الأعراف: 131]. وكانت إذاذ أراد أحدهم أمرا كسفر وغيره أمسك بطائر ثم أرسله، فإن ذهب يمينا تفاءل ومضى في أمره، وإن ذهب شمالا تشاءم ورجع عما أراد، وقد بيّن النبي حكم هذا العمل بقوله: الطير شرك "32 - تين.

وفي فتاوى المعاصرة للدكتور وهبة

الزحيلي: "ولا تشاءم بالطيور، ولا يصح الاعتقاد بأنّ دابة تخرج من رأس القتيل أو تتولد من دمه، فلا تزال تصيح حتى يؤجذ بثأره كما

31 الشيخ عبد الرحمن بن حسن آل الشيخ، فتح المجيد شرح كتاب

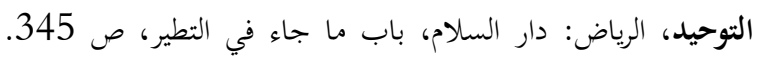

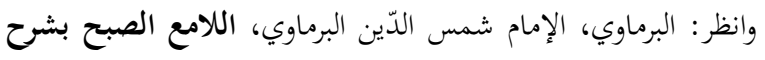

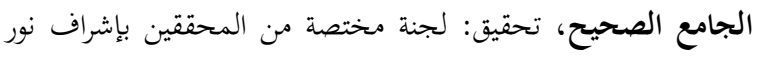

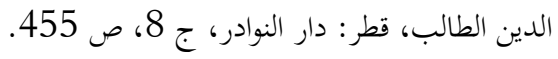

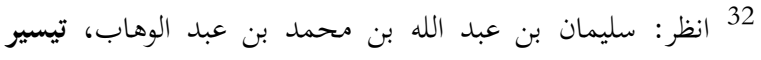

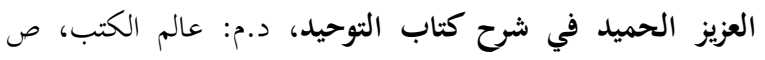


طيرة، والطيرة على من تطير، وإن تكن في

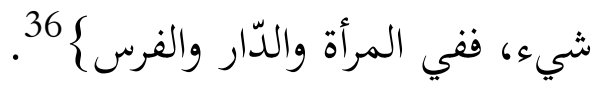

وذلك كما ذكر القرطبي عن إمكانية

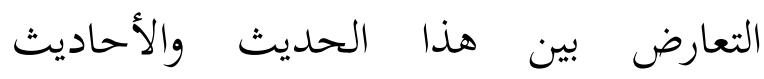
الصحيحة الأخرى بقوله: "وقال (أبو عمر): هذا يوجب أن تكون الطيرة في الدّار والمرأة

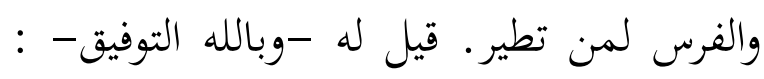

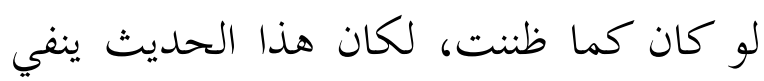
بعضها بعضا. لأن قوله لا طيرة، نفي لها،

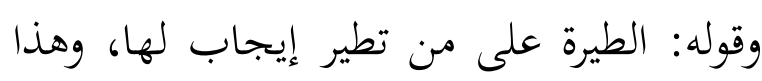
محال أن يظن بالنبي مثل هذا النفي والإثبات

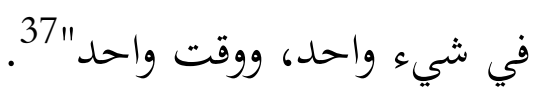

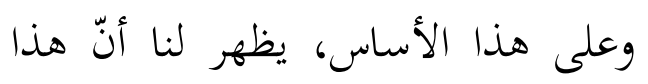

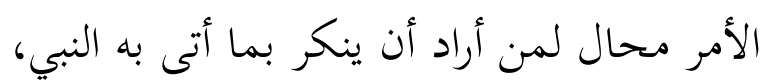

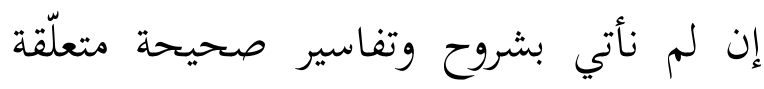
بهذا الحديث، لتوضيح عدم تعارض الحديث بأحاديث صحيحة أخرى، ونبيّن لهم قصد الثداريخ الحديث

36 أخرجه ابن حبان في صحيحه (انظر: الفتح 12-323)، قد روى عيد

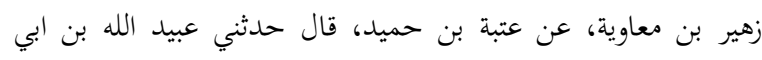

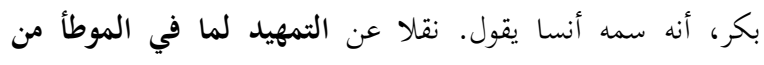
المعاني والأسانيد، للقرطبي.

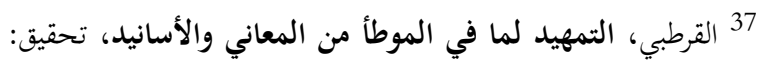

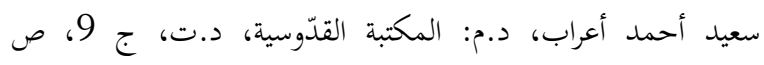
.285-284
نفسه شيء من ذلك) ولكن الله يذهبه

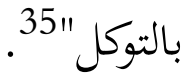

ويظهر لنا ممّا سبق أنّ الشؤم هو

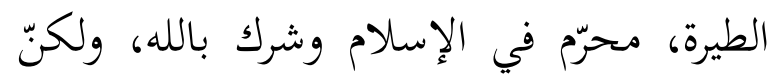

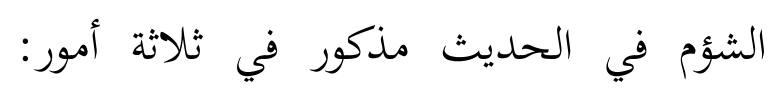

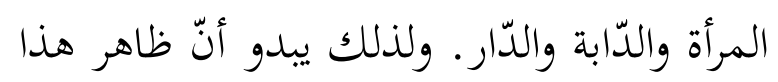

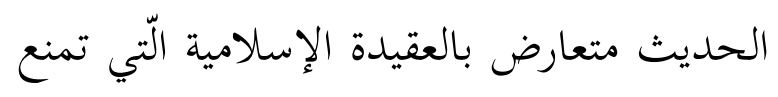
من التطير والتشاؤم، حتى ظنّ بعض النّاس أنّ النّا

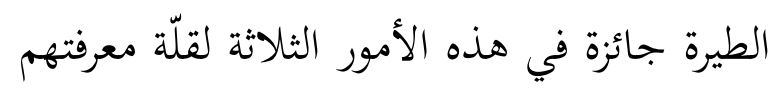
عن قصد الحديث ومفهومه الصّحيح.

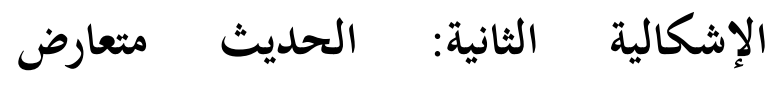
بالأحاديث الصحيحة الأخرى الإليه كما ذكرنا في الإشكالية الأولى أنّ الطيرة

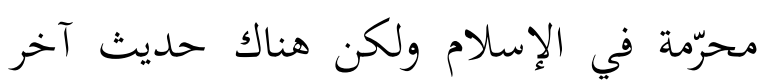

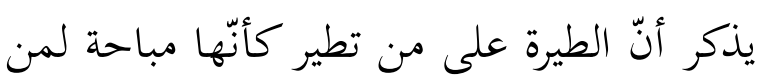

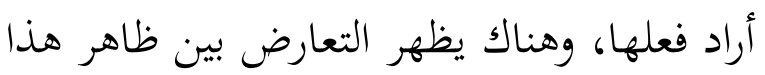
الحديث بأحاديث صحيحة أخرى تحرّم

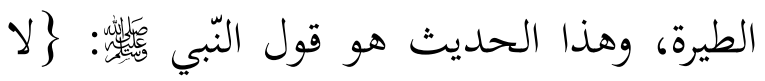

\footnotetext{
35 الشيخ كامل عويضة، جامع الفتاوى المعاصرة من السلف الصالح

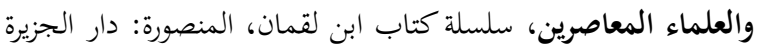

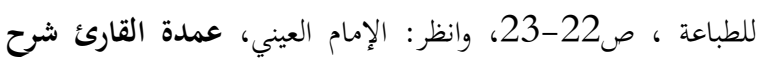
صحيح البخاري، المصدر السابق، ج14، صو صنط الامام العين، عمدة 213.
} 
السماء وشقة في الأرض فقالت: والذي أنزل القرآن على محمد ما قالها رسول الله قط، إنّما كان أهل الجاهلية يتطيرون من ذلك 39". وهناك حديث آخر يوضّح رفض عائشة للحديث رواه أحمد وابن خزيمة والحاكم من ونم

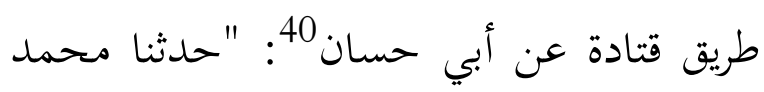

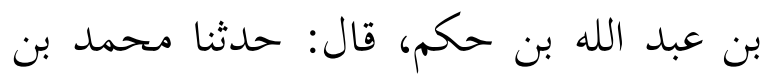
معاوية ابن عبد الرحمان، قال: حدثنا إسحاق بن أبي حسان، قال: حدثنا هشام ابن عمار، قال: حدثنا الوليد بن مسلم، عن سعيد، عن قتادة، عن أبي حسان أن رجلين دخلا على عائشة وقالا: إن أبا هريرة يحدث أنّ النبي قال: إنّما الطيرة في المرأة والدّار والدّابة. فطارت شقة منها في السماء، وشقة في الأرض ثم قالت: كذب -والذي أنزل الفرقان- على أبي القاسم، من حدث عنه بهذا؟ ولكن رسول الله كان يقول: كان أهل الجاهلية يقولون: الطيرة

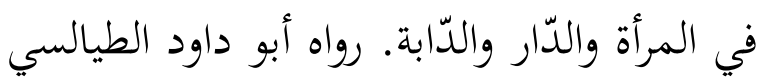

39 البوصيري، إتحاف الحيرة المهرة بزوائد المسانيد العشرة،

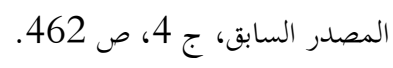

40 الخطابي، إعلام السنن في شرح صحيح البخاري، بيروت: دار

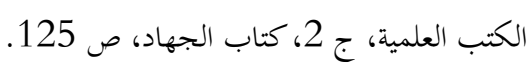

الحديث الأصلي لبيان وحدة الموضوع في السنّة النبوية المطهّرة، لا يتعارض بعضه ببعض.

الإشكالية الثالثة: الادعاء برفض عائشة هذ

\section{الحديث}

هناك من يأتي برفض عائشة هذا الحديث، الحدابث منها كما قال البوصيري: "قال أبو داود البالي

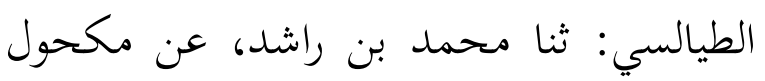

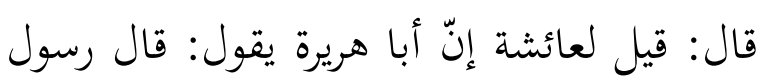

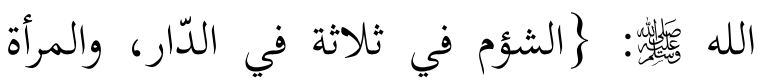
والفرس\{ فقالت عائشة: لم يحفظ أبو هريرة،

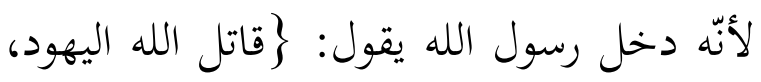

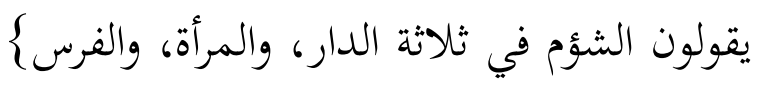
فسمع آخر الحديث ولم يسمع أوّله" 38 فئل وكذلك هذا الحديث يبيّن رفضها:

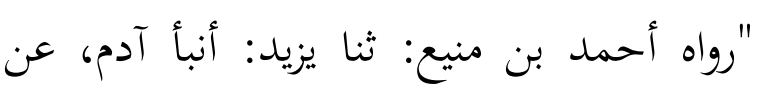

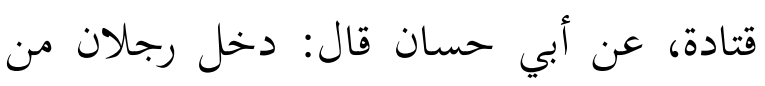
بني عامر على عائشة فأخبراها أنّ أبا هريرة

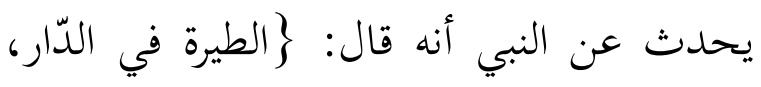

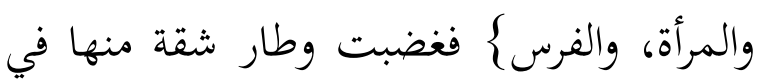

38 البوصيري، إتحاف الحيرة المهرة بزوائد المسانيد العشرة،

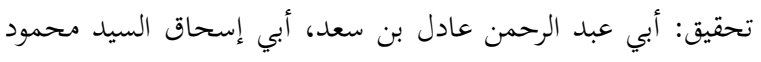

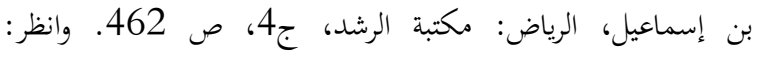
المنّاوي، اليواقيت والدرر في شرح نخبة ابن حجر، تحقيق: الدكتور

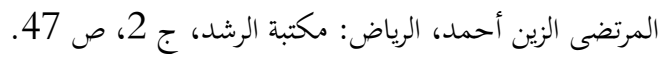


وقال عنه كذلك العيني عن النسخ حين

يذكر الاحتمال الثاني عنده في الحديث:

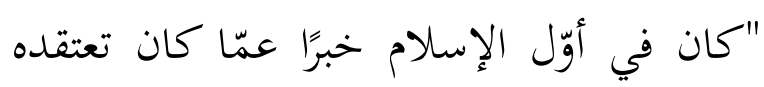
العرب في جاهليتها على ما قالت عائشة، ثم الثمان نسخ ذلك وأبطله القرآن والسنن وأخبار الآحاد لا تقطع على عينها، وإنما توجب العمل فقط"

ويوضّح لنا من خلال البيانات والاحتمالات السابقة أنّ هذا الحديث كان النان منسوخ لكونه خبرًا لاعتقاد العرب في الجاهلية وقد نُسخ بالآية القرآنية والأحاديث الصحيحة لاعتقاد العرب في الجاهلة الأخرى التي تبيّن تحريم الطيرة في الإسلام. ومن الملاحظ أنّ هذا الأمر يحتاج إلى بيان.

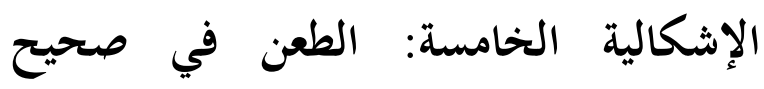
البخاري لحمل الحديث يشتمل على شرك

\section{صريح}

أشارت الاشكاليات السابقة إلى أنّ هناك

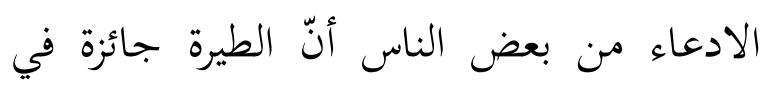
الثلاث المذكور في الحديث. وانطلاقًا من من الداء

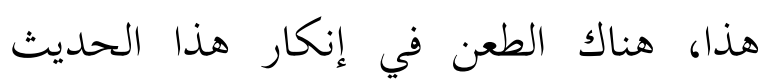

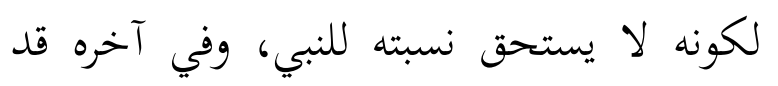

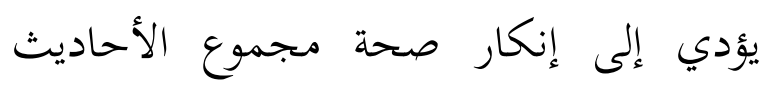

43 العيني، عمدة القارئ شرح صحيح البخاري، المصدر السابق،

$$
\text { ج 14، ص العين، عمدة } 211 .
$$

في مسنده في مكحول، وأحمد بن خزيمة من طريق قتادة" ف14. فيناه في

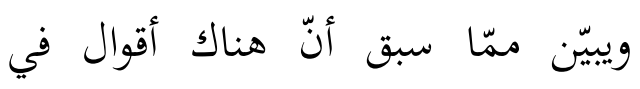
رفض عائشة لحديث الشؤم في المرأة والدار

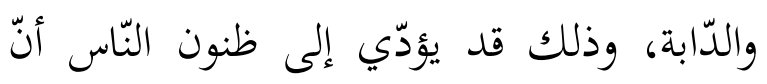

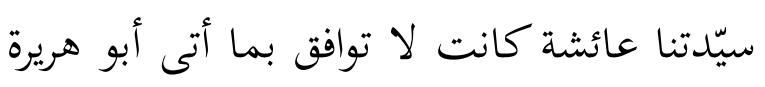
من حديث فقالت فيه كذب، وبيّنت أنّ الأمور

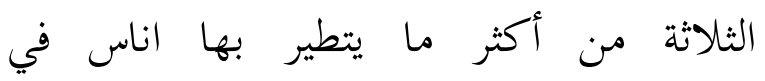
الجاهلية. وبهذا، فلا شكُّ أنّ هذا الأمر يحتاج إلى بيان وتوضيح.

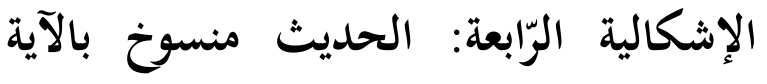 والأحاديث الصحيحة الأخرى}

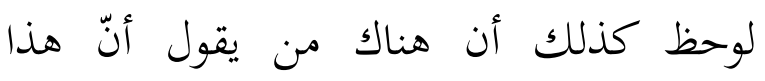
الحديث منسوخ بالآية القرآنية والأحاديث

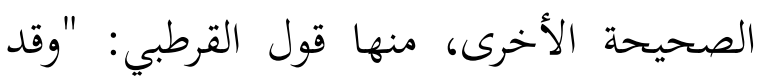

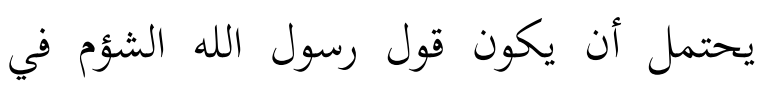

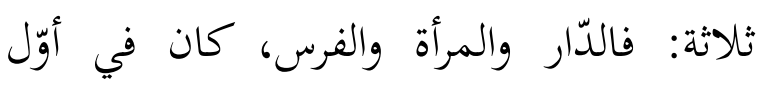

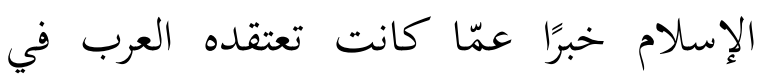

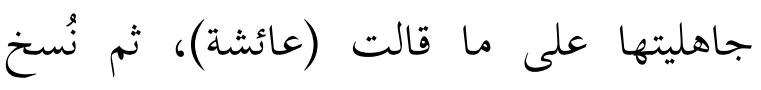
ذلك وأبطله القرآن والسنة"

41 القرطي، التهيديد لما في الموطأ من الدعاني والأسانيد، المصدر

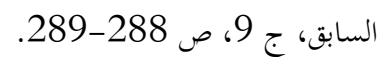
42 القرطي، التهيد لما في الموطأ من المعاني والأسانيد، المصدر

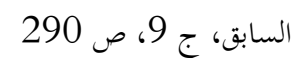


ويتّخح لنا من خلال الأقوال أنّ هناك

محال لمنكري السنّة أن يطعن في صحيح

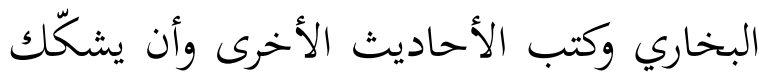
في نسبة الأحاديث في كتب السنّة إلى النبّي، وخصوصًا صحيح البخاري ومسلم، ولا شكّ فيه أنّ هذا الأمر خطير ويحتاج إلى بيان. ولذلك من خلال هذه الإشكاليات،

ترى الباحثة أنّ هناك التساؤلات المحتاجة إلى الجواب. ومن بينها؛

الأول: هل الشؤم أو الطيرة حرام أم جائز في الإسلام لكون ثبوت الشؤم في الأمور الثلاثة المذكورة في الحديث؟ والثاني: لماذا ذكر النبي عن الشؤم في ثلاثة الأمور رغم أن الطيرة محرّمة في الإسلام؟ والثالث: لماذا رفضت عائشة الحديث وقالت في أبي هريرة كذب؟ وهل أحاديث رفضها من أحاديث صحيحة؟ بـ والرّابع: كيف نحلّل المشكلة في تعارض الحديث بالأحاديث الصحيحة

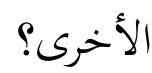

العقيدة. وانظر: طه جيشي، من كتاب ضلالات منكري السنة،

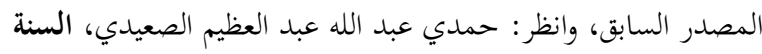

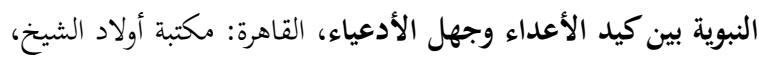

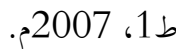

الصحيحة في كتب السنّة، وخصوصًا صحيح البخاري، مع الطعن أنّه يحمل الحديث فيه شرك صريح بالله.

وكلّ ذلك كما بيّنه د. طه جيشي في كتاب ضلالات منكري السنة: "في هذا الحديث يرى منكرو السنة أنهّ لا يصح نسبته إلى النّب؛ لأنه يشتمل على شرك صريح، وذلك لأنّ الحديث يشير مضمونه إلى أنّ المرأة والدّار والفرس مصادر للشرّ باستقالالها، وأنّ المؤمن يجب عليه أن يعتقد ذلك، ولا شك أنّ ملّ

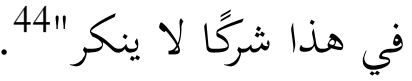
وكذلك مذكور في الموقع الإلكترونية بيان الإسلام: يدّعي بعض المشكَكين أنّ إِّ صحيح البخاري قد حوى أحاديث تخالف

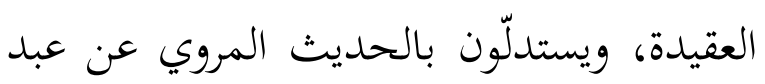

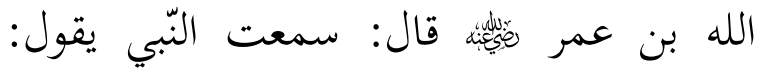
\} إنما الشؤم في ثناثة في الفرس والمرأة والدار \{؛ فيهدفون من وراء ذلك إلى الطعن في

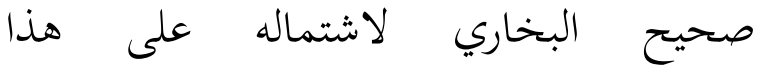
الحديث 45

44 طه جيشي، كتاب ضلالات منكري السنة، ط 2، القاهرة: مطبعة رشوان، 1427هـ، 2006م. كناب مات

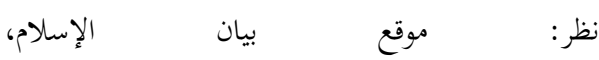
http://bayanelislam.net/Suspicion.aspx?id=03-01(152\#_edn3 
إن الشؤم في الأمور الثلاثة التي ذكرها النبي في نظر العلماء ليس من الطيرة المحرّمة التي منعها

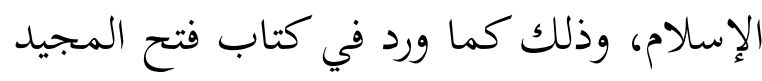
شرح كتاب التوحيد: "وقال ابن القيم: إخباره بالشؤم في هذه الثلاثة، ليس فيه إثبات الطيرة

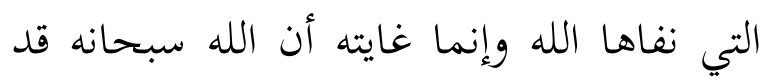
يخلق أعيانا منها مشؤومة على من قاربها

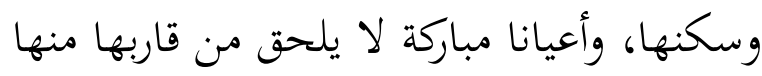

$$
\text { شؤم ولا شر "46. }
$$

وتوضّح الشيخ عبد الرحمن بن حسن آل الشيخ كلام ابن القيم بالتّفصيل: "والله

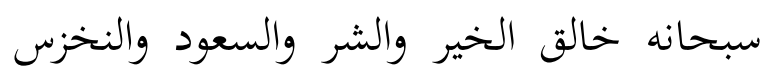

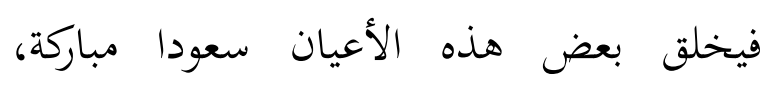
ويقضي بسعادة من قاربها وحصول اليمن ليخن والبركة له، ويخلق بعضها نخوسا يتنحس بها بها من قاربها، وكل ذلك بقضائه وقدره كما خلق


والمختلفة، كما خلق المسك وغيره من الأرواح

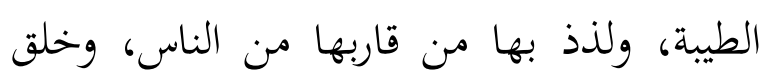

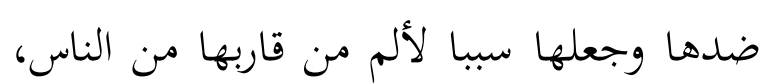

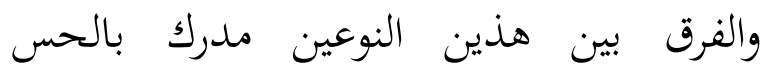

46 الشيخ عبد الرحمن بن حسن آل الشيخ، فتح المجيد شرح كتاب



والخامس: كيف نردّ على الشبهات المنتجة من سوء فهم الناس على هذا الحديث؟

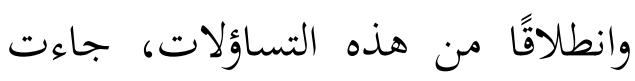
الباحثة بمحاولتها لحلّ تلك الإشكاليات الخمسة، وذلك من خلال مناقشة أقوال

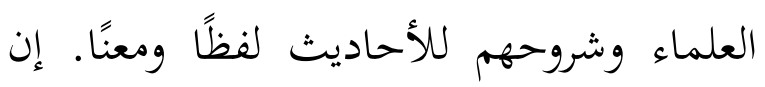
شاء الله تعالى. الى حلول الإشكاليات الخمسة للحديث:

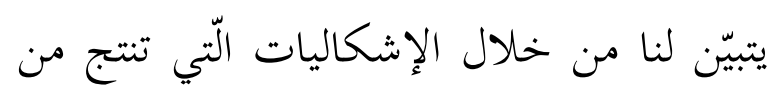

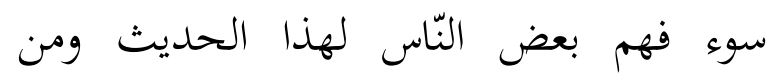
جهالتهم بقصده. ولذا، لا بدّ من اقتراح الحلول

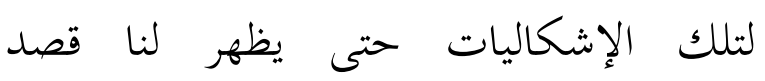
الحديث ومفهومه الأصلي. وقسّمت الباحثة هذه الحلول إلى سبعة؛ أوّلها: الشؤم المذكور

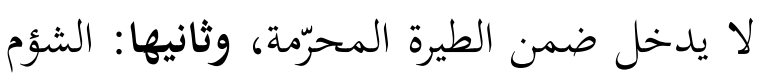

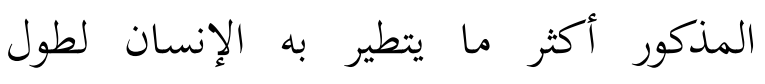

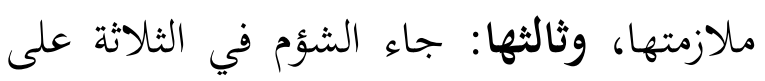
معناه الخاص، ورابعها: قول عائشة في أبي

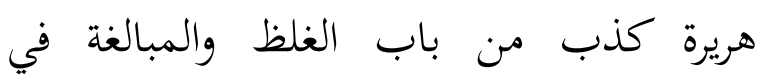
الغضب، وخامسها: لا يثبت أن الحديث

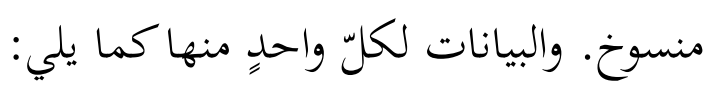

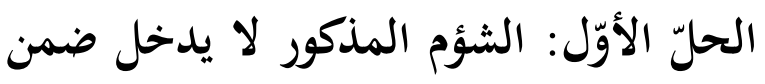

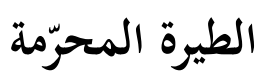


من هذا أنّ الثؤم في الأمور الثلاثة ليس من الطيرة المحرمة المنهي عنها النبي في الحديث

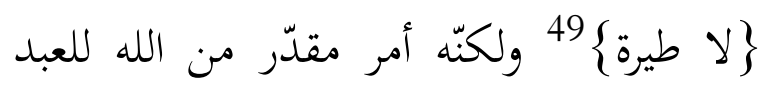
بقضائه. ولذا، قال الكرماني: قال الخطابي هذه الأشياء ليس لها في نفسها فعل وتأثير وإنما ذلك بمشيئة الله 50.

وكذلك بيّن البرماوي هذا الأمر في بي

اللامع الصبح بشرح الجامع الصّحيح، استنادًا بأقوال الخطابي وابن قتيبة أنّ الشؤم الذي ذكره النبّي في الحديث هو مستثنى من الطيرة، أي: الطيرة منهي عنها إلّا أن يكون له دار يكره

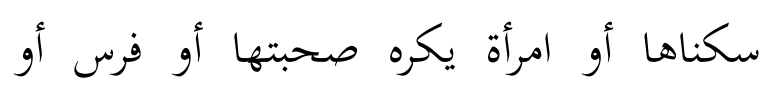
خادم، وإذا وجد أحد النّاس بهذا، فينبغي عليه تركها، فليفارق الجميع؛ بالبيع والطلاق ونحوه،

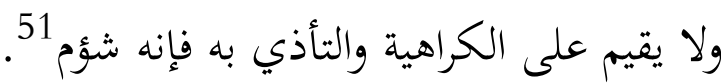
وزاد البرماوي أنّ هذه الأشياء الثلاثة ظروف ليس لها تأثير والإضافة إليها إضافة مكان، لأنّ كلّما يصيب الإنسان من الخير

49 انظر: البخاري، صحيح البخاري، كتاب الطب، باب الطيرة، حديث رقم 5754، المصدر السابق، ص 1469.

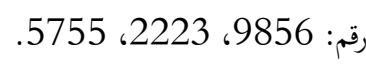

50 انظر: الكرماني، صحيح البخاري بشرح الكرماني، ط2 256 ، بيروت:

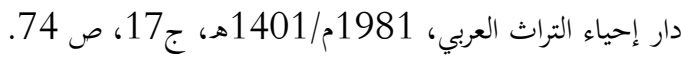

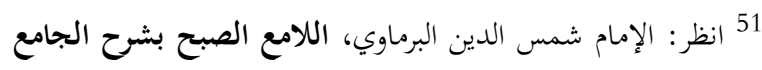

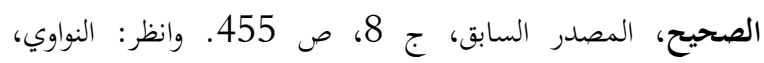

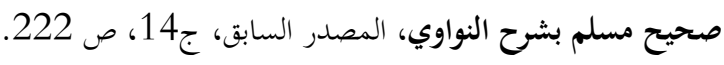

فكذلك في الديار والنساء والخيل فهذا لون والطيرة الشركية لون. انتهى" لنكئ.

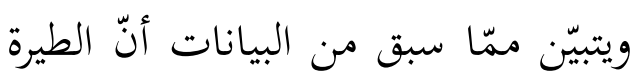
تنقسم إلى نوعان: الطيرة الشركية والطيرة غير الشركية. ويمكن أن نفهم من هنا أنّ الطيرة



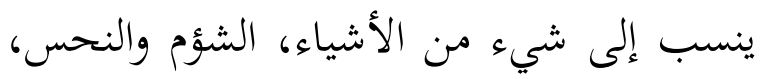

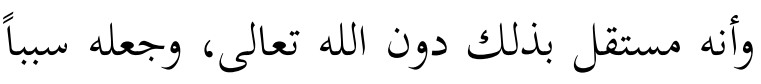

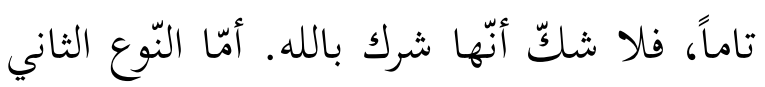
من الطيرة ففي بعض الأشياء الّي قدّر الله

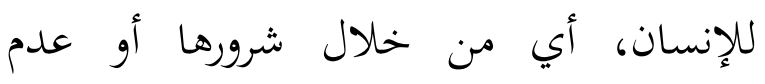

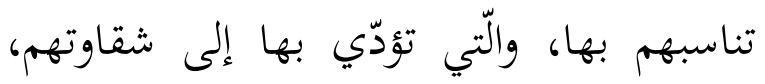
وهذا النّوع من الطيرة غير الشركية، وأنّها تتعلّق بقدر الله تعالى على العبد، فيطردها بالتوكل على الله والدّعاء. وبيّن النواوي حقيقة الشؤم الذي ذكره

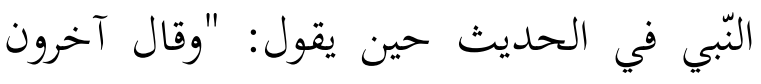
شؤم الدّار ضيقها وسوء جيرانها وأذاهم وشؤم ونال المرأة عدم ولادتها وسلاطة لسانها وتعرضها للريب وشؤم الفرس أن لا يغزى عليها؛ وقيل

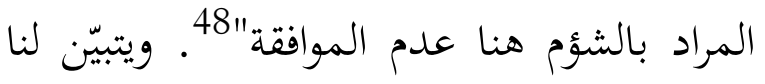

$$
47 \text { المصدر نفسه، ص } 485 .
$$

48 النواوي، صحيح مسلم بشرح النواوي، المصدر نفسه، ج14،

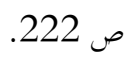


من الطيرة الممنوعة، ويمكن أن نقول أنّها شر

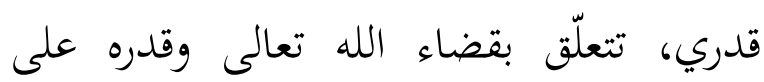
الإنسان، مثل أن يجد بعض النّاس الشؤم في

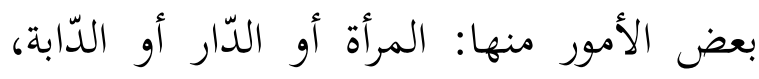

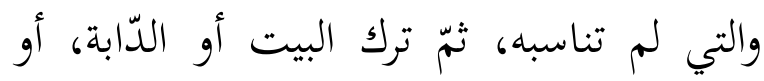

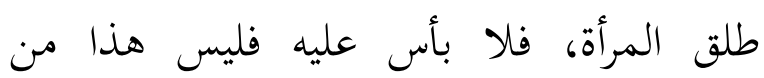
الطيرة.

الحلّ الثّاني: الشؤم المذكور أكثر ما يتطير به الإنسان لطول ملازمتها ذكر الحافظ ابن حجر العسقلاني كلام ابن

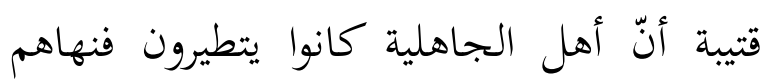



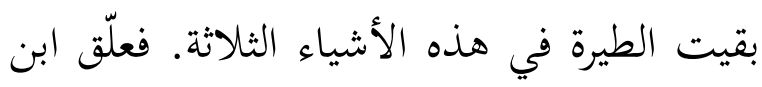
حجر به فقال: فمشى ابن قتيبة على ظاهره،

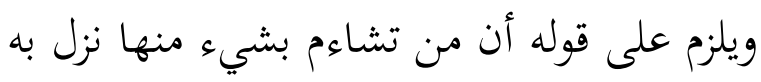

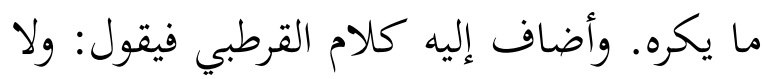
يظن به أنه يحمله على ما كانت الجاهلية

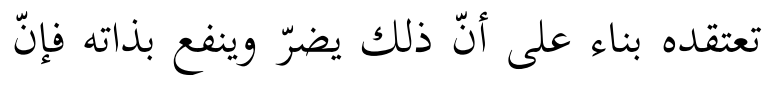

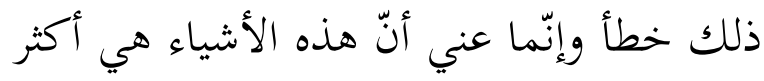
ما يتطير به النّاس، فمن وقع في نفسه شيء

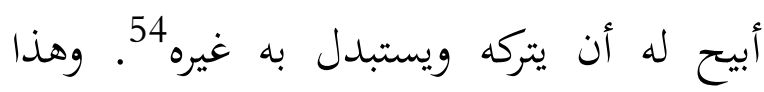

54انظر: الحافظ ابن حجر العسقلاني، فتح الباري شرح صحيح

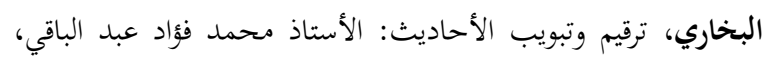

والشر لا يكون إلا بقضاء الله، فاليمن أو الشؤم يكون علامة على خير هذه الأشياء أو شرّها،

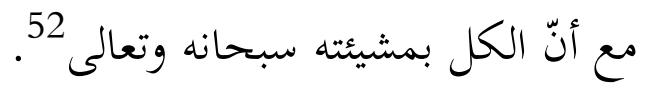
وإضافة إلى هذا، ذكر الإمام النّواوي

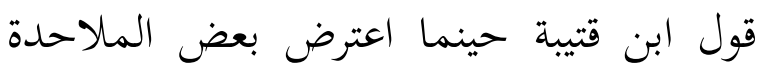
بحديث، قأتى بتقسيم الطيرة إلى ثلاثة؛

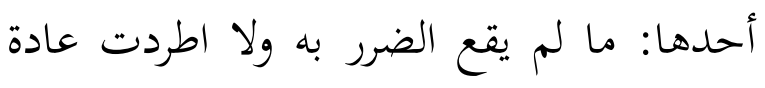

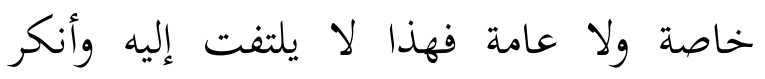

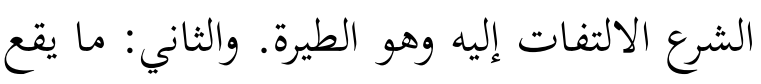

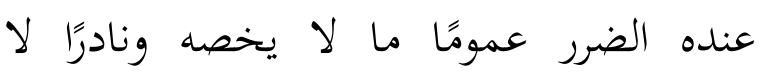

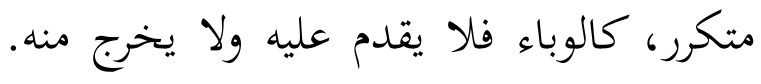
والثالث: ما يخص ولا يعم كالدّار والفرس لئر والمرأة فهذا يباح الفرار منه م3 53 ونخلص من البيانات والشروح السابقة

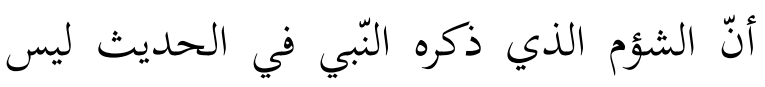

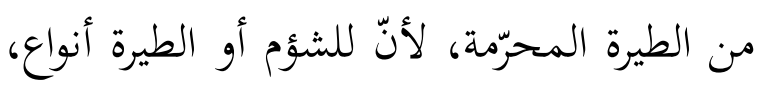

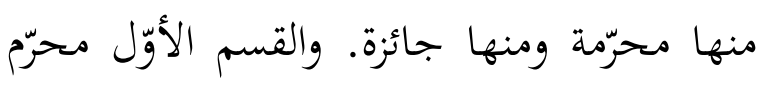
شرعًا بلا شك، وهو التشاؤم من المرئيات أو أو التر المسموعات من دون الله، فلا يجوز؛ أمّا القسم الثّاني فمستثناة من الشؤم الشركي، وليس لهات

52 انظر: الإمام شمس الدين البرماوي، اللامع الصبح بشح الجامع

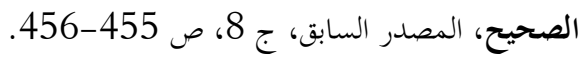
53 انظر: الإمام النواوي، صحيح مسلم بشح النواوي، المصدر

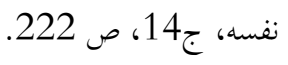


ذكر الأشياء الثلاثة في الحديث لأنّه إن كان خلق الله الشؤم في شيء مما جرى من بعض العادة، فإنّما يخلقه في هذه الأشياء، أو لنقول إن كان الشؤم في شيء حقّا، فهذه الثلاث أحقّ به، لأنّ النّاس يقع فيها التشاؤم بهذه أكثر فئر فئره مما يقع بغيرها وعلاوة على ذلك، قد بيّن ابن العربي

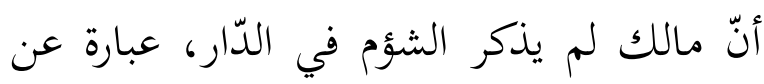
جري العادة فيها، وأشار إلى الأمر بالخروج من فئن الدّار صيانة لاعتقاده عن التعلق بالباطل. وقيل أنّ هذا الحديث جاء بمعنى: لو لم يعتقد الإنسان الشؤم في هذه الأشياء ولكن يطول تعذيب القلب بها مع كراهة أمرها لملازمتها بالسكنى والصحيبية، فأشار الحديث إلى الأمر بفراقها ليزول التعذيب. ووافق الحافظ بهذا بهابيها

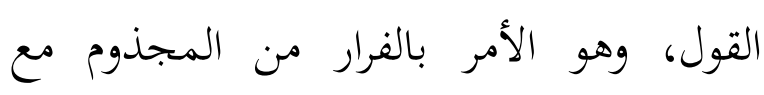

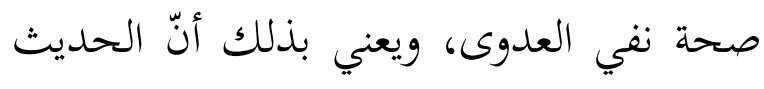

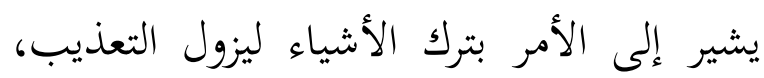

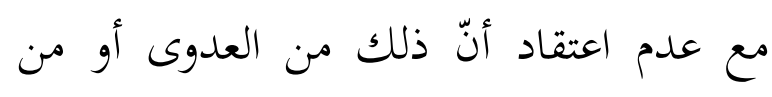

57 انظر: الحافظ ابن حجر العسقلاني، فتح الباري شح صحيح

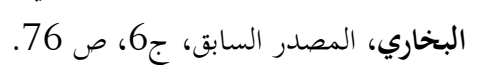

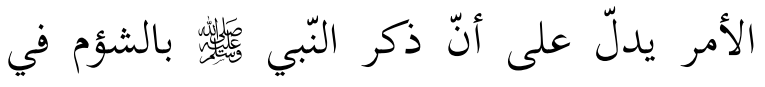

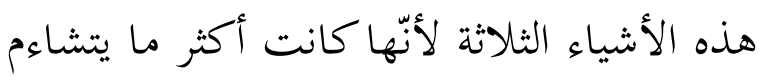

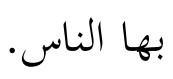
وذلك كما ذكره القرطبي والسّيوطي والفاسي وعلي الصعيدي في تفاسيرهم للحديث أنّ هذه الأشياء الثلاثة هي أكثر ما في الفيا

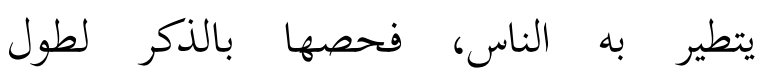

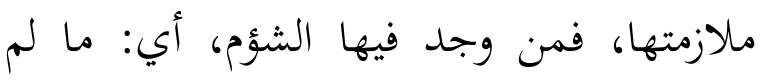

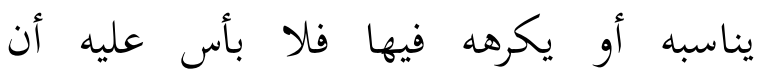
يفارقه 55. ويظهر من ذلك أنّ هذه الأشياء الثلاثة هي أكثر ما يتشاءم بها النّاس لأنّ النّاء غالب أحوالهم لا يستغني عن دار يسكنها، وزوجة يعاشرها، وفرس أو الدّابة56.

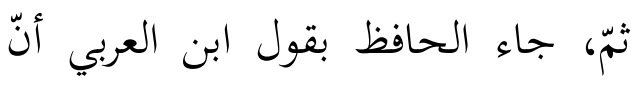

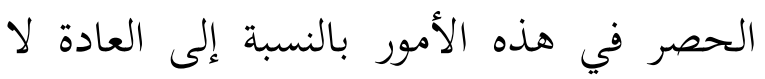

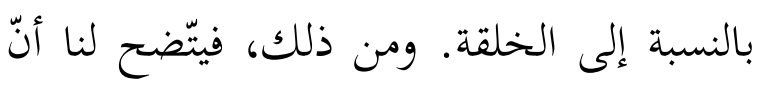
تحقيق: عبد العزيز بن عبد الله بن باز، بيروت: دار الكتب العلمية،

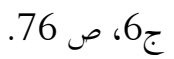
55 انظر: الحافظ ابن حجر العسقاني، فتح الباري شرح صحيح

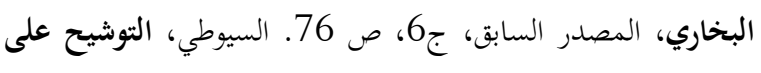

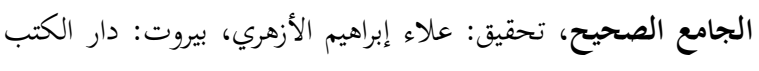

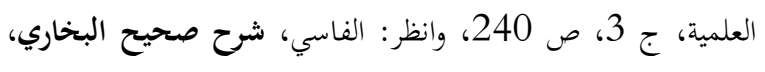

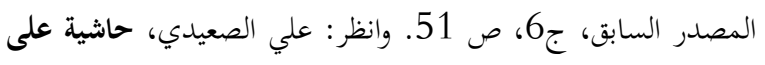
كفاية الطالب الرباني لرسالة ابن أبي زيد القيرواني، المصدر السابق، على ص 395. 56 انظر: العيني، عمدة القارئ شح صحيح البخاري، المصدر

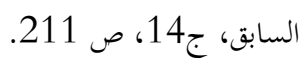


القرطبي والعيني وأبو يحي بن محمد

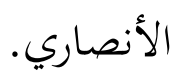

يبيّن ذلك قول مالك أنّ الله قد يجعل

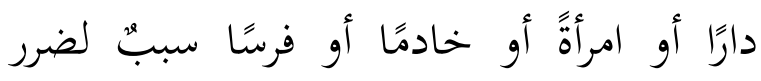
النفس أو هلاكه، وذلك بقضاء الله تعالى، ويعني به أنّ أحدًا قد يحصل لشؤم في هذه وكاء الثلاثة59. وذكر عنه كذلك القاضي عياض إنّ إن فئن الشؤم في الحديث على ظاهره، وذلك بجري العادة من قدر الله في ذلك، وقد سمي مالك كل مكروه ومحذور : شؤم ومشاءمة والمشأمة أيضا60. وكذلك يقول ابن العربي حين يفسّر كلمة الثؤم بالمكروه، أي: وصول المكروه إلى إئ لعربي الشخص بسبب يصل إليه من مسكن أو مخالطة فيدخل فيه المرأة والفرس. وأضاف إليه

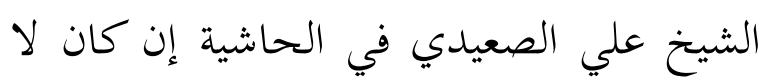
وجود له في الثلاثة فلا وجود له أصلاً 61.

59 انظر: الإمام النواوي، صحيح مسلم بشرح النواوي، المصدر

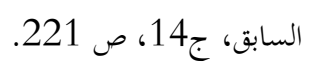
60 انظر: القاضي عياض، مشارق الأنوار على صحاح الآثار في شرح غريب الحديث الموطأ والبخاري ومسلم، المصدر السابق،

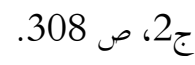
61 انظر: علي الصعيدي، حاشية على كفاية الطالب الرباني لرسالة

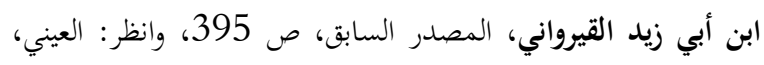

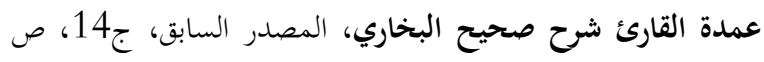

الطيرة، لأنّه قد يقع النفس في اعتقاد ما نهي عنه، ومن الأولى أن يجتنب منه لـأل ويظهر لنا من خلال البيانات والشّروح السابقة أنّ الشؤم المذكور في الحديث هو دلالة على شيء أكثر ما يتطير أو يتشاءم بها الإنسان، لأنّهم في غالب الأحيان، لا يستغني

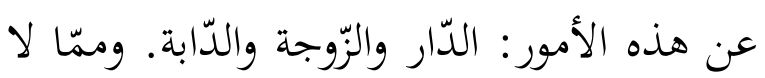
شكّ فيه أنّ في بعض الأحيان، قد يقع النقس في الأمر الذي لم يناسبه ويكرهه، فطال تعذيب القلب به، فلا بأس عليه أن يتركه ويستبدل به غيره ليزول التعذيب، دون أن يعتقد

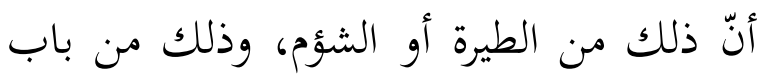
سدّ الذريعة، لألّا يقع في اعتقاد منهي عنه في الإسالام.

الحلّ الثّالث: الثؤم في الأمور الثلاثة على

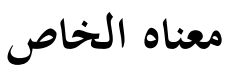
هناك من العلماء يقولون أنّ الشؤم في الثلاثة

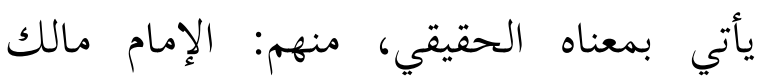
والقاضي عياض والبرماوي، كما يرى بعضهم الآخر أنّه ليس على ظاهره بل نسبية له، منهم:

58 انظر: الحافظ ابن حجر العسقلاني، فتح الباري شح صحيح

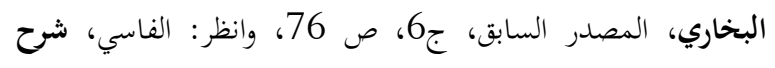

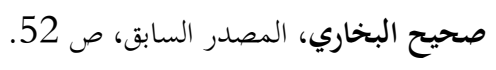


وذهب الحافظ ابن حجر إلى و إلّا فالشؤم لا يختص بها، وشؤم الفرس اختصاص الشؤم ببعض النساء دون بعض ممّا شموسها أو أن لا تستعمل في سبيل الله وشؤم دلت عليه الآية من التبعيض، وكذلك الدّار المرأة أن تكون سليطة أو غير ولود، أو غير والفرس، ويعني بهذا ألّا يكون الشؤم في كلّ قانعة وشؤم الدّار سوء الجوار أو الضيقة أو هذه الأمور بل في بعضها، كما في الدّار ضيق البعيدة من المسجد لا يسمع فيها الآذان"65.

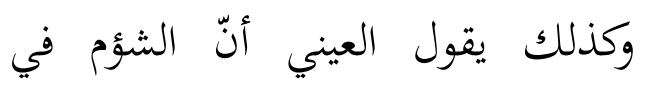
الحديث لا يأتي معناه على ظاهره لأنّ قوله: الا طيرة\{، وهي نكرة في سياق النفي، فتعم الأشياء التي يتطير بها، وإن كان الشؤم في

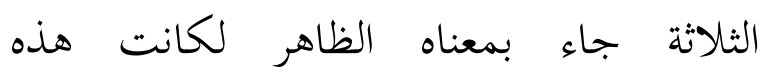
الأحاديث ينفي بعضها بعضا. وهذا محال أن يظن بالنبي مثل هذا الإختلاف في النفي والإثبات، في شيء واحد ووقت واحد بكل.66.

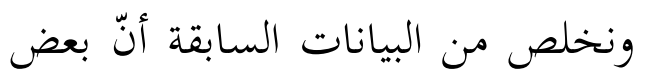
العلماء يرون معنى الشؤم في الأمور الثلاثة هو على ظاهره، فيفسّر الشؤم بالمكروه والمحذور. وفيه أقوال، منها: الشؤم في الثلاثة من التبعيض وهو اختصاصه لبعض دون بعض، ومنها: عام مخصوص. وغير ذلك، يرى بعض العلماء أنّ الشؤم في الثلاثة على غير ظاهره، بل الحصر

65 أبو يحي زكريا بن محمد الأنصاري، تحفة الباري بشرح صحيح

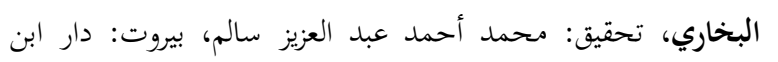

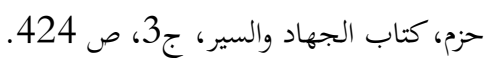
66 انظر: العيني، عمدة القارئ شرح صحيح البخاري، المصدر صن

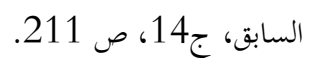
ساحتها وخبث جيرانها، والدّابة منعها ظهرها وسوء طبعها، والزوجة أو المرأة عقم رحمها

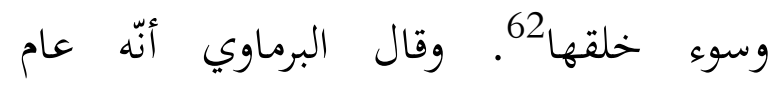
مخصوص، فإنه كالمستثنى من ذلك، أي: إلا أن يكون له دار يكره سكناها، أو امرأة يكره صحبتها، أو فرس كذلك؛ فليفارقهن. فجاء

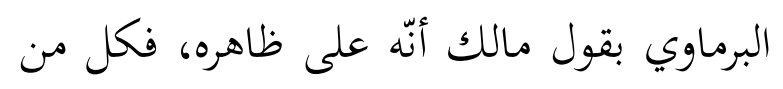
الثلاثة قد يكون سببًا للضرر 63. والعكس على ذلك، ذهب القرطبي إلى أنّ الشؤم في الدّار والمرأة والفرس عنده على غير ظاهرة64. كما يقول أبو يحي زكريا لهري الأنصاري: "الحصر في الثلاثة نسبي بالنّر إلى الأعم الأغلب فيما يحتاج إليه لا حقيقي

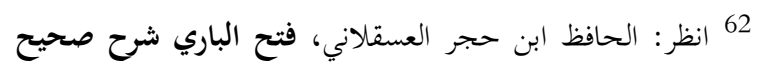

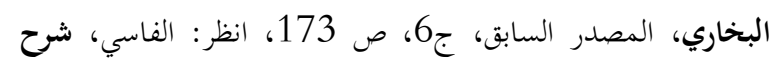

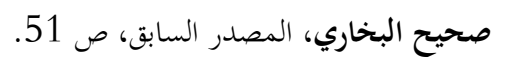
63 انظر: البرماوي، اللامع الصبح بشرح الجاري، الدمر الصاق، صحسيح، المصدر

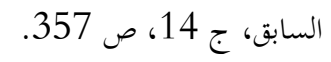
64 انظر: القرطبي، التمهيد لما في الموطأ من المعاني والأسانيد،

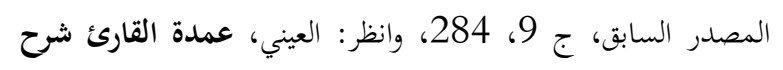
صحيح البخاري، المصدر السابق، ج14، ص صانظر : العني، عمدة 211. 
قال: فأنكره"67. ويبيّن لنا ممّا سبق أنّ هذا

$$
\text { الحديث مرسل درجته. - (مال. }
$$

وعلاوةٌ على ذلك، قد بيّن العيني أنّ درجيّ رفض عائشة عن الحديث هو على سبيل الإخبار عن حكاية الجاهلية فيقول: فأخبرت عائشة أن ذلك القول كان من النبي حكاية عن أهل الجاهلية، لا أنه عنده كذلك، وذلك لأنّهم كانوا يعتقدون الشؤم في هذه الثلاثة، وليس كما في اعتقاد بعض المسلمين أنّ الشؤم حاصل في هذه الثلاثة. وفي قول عائشة في أبي هريرة كذب، وقد روى بعض العلماء أنهّ يشير إلى المبالغة في الغضب والغيظ، كما قال أبو عمر أنّ العرب تقول: كذبت إذا أرادوا به التغليظ، ومعناه: غلطت فيما قدرت، وأوهم وظن حقّا، ونحو ذلك 68. ووضّح ذلك القرطبي إستنادًا إلى قول أبي عمر أنّ هذا ليس من الكذب الذي هو ضد الصدق، وإنما هو من باب الغلط والظن ما ليس بصحيح؛ وذلك أنّ قريشا زعموا أنّهم يخرجون بني هاشم من مكة إن لم يتركوا جوار

67 المنّاوي، اليواقيت والدرر في شرح نخبة ابن حجر، المصدر

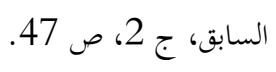

68 انظر: العيني، عمدة القارئ شح صن صحيح البخاري، المصدر

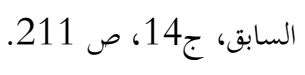

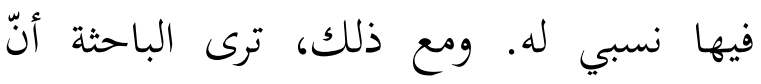

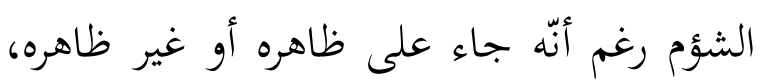
فقد يفيد معنى: شؤم الدّار: ضيقها وسوء

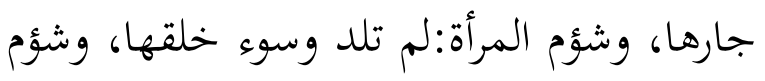
الفرس: أنه لا يغزى بها. والله أعلم.

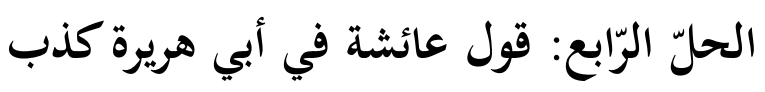

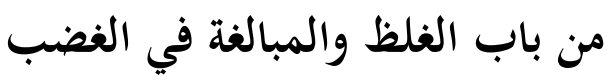
وقبل أن نتعمّق في بيان أحاديث التي يتضمّن

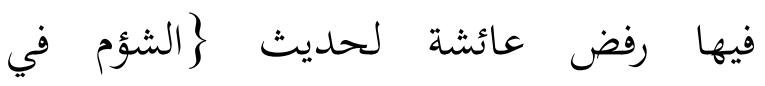
الثلاث\{، لنبدأ بتعبين درجة الأحاديث أولَاً،

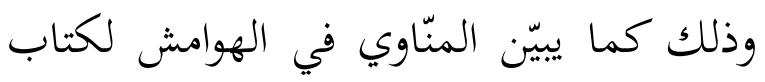

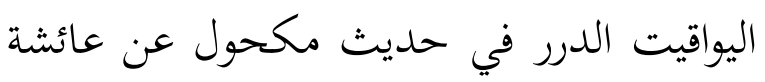

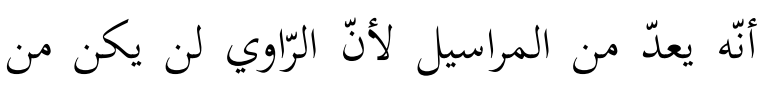

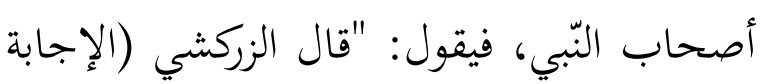

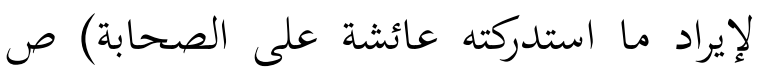
103: (ومحمد بن راشد وثقه أحمد وغيره. ولكن الشك في الواسطة بين مكحول وعائشة.

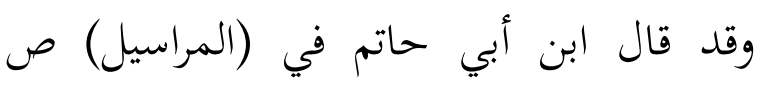

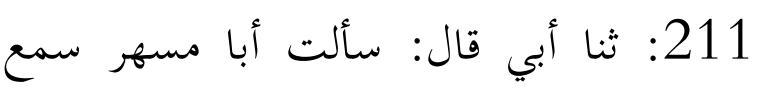

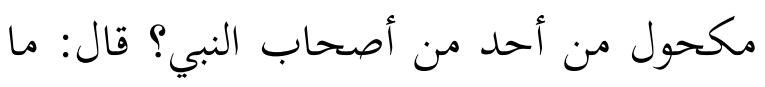




أهل الجاهلية واعتقاداتهم كقول العيني، والثّاني: إنّه ليس على وجه الإخبار بل ممّا يلزم المسلم أن يعتقدوه كقول الخطابي.

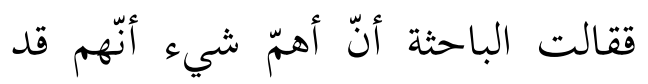
اتفّقوا على أنّ رفض عائشة الحديث ليس على وجه الإنكار للحديث، بل على وجه الظّّن ما لـا يحتمل الخطأ، وكان قولها في أبي هريرة كذب ولإب من باب الغلط والظن ما ليس بصحيح، مع الذّكر بأنّ قول الشؤم في الثلاثة ليس مجرّد الإخبار عن حكاية الجاهلية بل حاصل فيها أقرب من الصواب عندي.

الحلّ الخامس: لا يثبت أن الحديث منسوخ ورد الحافظ ابن حجر العسقلاني في فتح الباري أنّ هناك من يقول بأنّ الحديث منسوخ

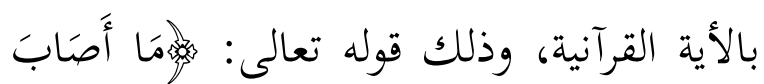

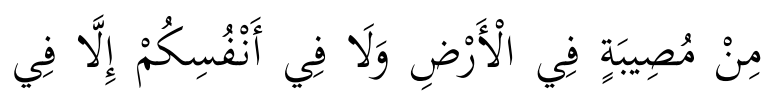

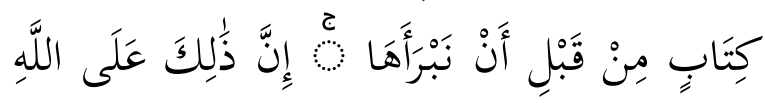

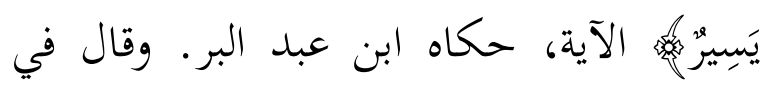
ذلك ابن حجر: والنسخ لا يثبت بالاحتمال، لا سيّما مع إمكان الجمع ولا سيّما وقد ورد في نفس هذا الخبر نفي التطير ثم إثباته في
محمد، فقال لهم أبو طالب: كذبتم؛ أي: غلطتم فيما قلتم وظنتم 69 . وذكر عنه الخطابي في إعلام السنن في شرح صحيح البخاري أنبّ لا معنى لإنكار ذلك على أبي هريرة مع موافقة من ذكرنا من الصحابة له 70. وبالرغم من ذلك، فإنّ الخطابي ذهب إلى القول أنّ الشؤم في الثلاثة ليس على وجه الإخبار لبيان اعتقاد الناس في ذلك، كما تأوله البعض على ذلك، فيقول أنّ سياق الأحاديث الصحيحة المتقدم ذكرها يبعد هذا التأويل، وورد فيه قول ابن العربي: أنّ هذا الجواب ساقط لأنه لم يبعث ليخبر النّاس عن معتقداتهم

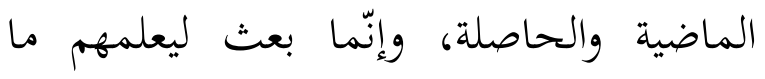
يلزمهم أن يعتقدوه 71. ونلاحظ من هنا أنّ الأحاديث فيها تئعدوه رفض عايشة حديث الشؤم تعدّ من المراسيل، وهذا موضوع. وموضوع آخر، نلاحظ أنّ هناك تأويلين لككام عائشة، الأوّل: إنّ الشؤم في الحديث جاء على وجه الإخبار عن حكاية

69 انظر: القرطبي، التمهيد لما في الموطأ من المعاني والأسانيد،

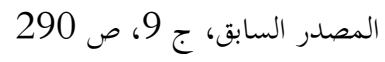

دار انظر: الخطابي، إعلام السنن في شرح صحيح البخاري، بيروت:

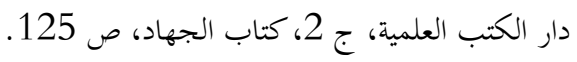



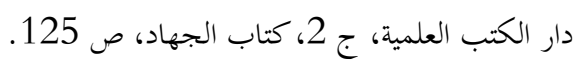


يتشاءم لم تكن مشؤومة عليه، فيكون التوكل عليه والثقة به والرجاء والخوف منه هو أعظم الأسباب التي يدفع بها الشر.

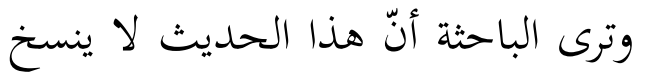

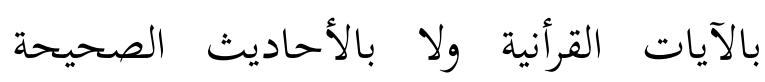
الأخرى بل يكمّل بعضها بعضا، مع بيانه الخاص. والله تعالى أعلم.

خاتمة إنّ حديث \}الشؤم في ثلاث؛ المرأة والدّار والفرس\{ هو من حديث صحيح، أخرجه مجموع الصّحاح والسنن والمسند، خاصةً صحيح البخاري ومسلم، وأنّه لا ينسخ بالآيات القرآنية والأحاديث الصحيحة الأخرى بل جاء بمعناه الخاص، ولو اطلّلنا على مفاهيمه الحقيقي، لوجدنا أنّ ليس فيه أي تعارض مع اطعلى لمعاه

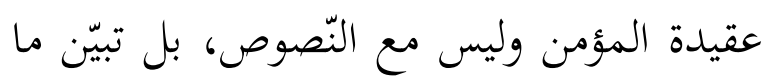
يلزم الاعتقاد به المسلمون، وهي تحريم الطيرة

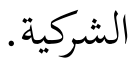

أمّا ذِكر النّبي الشؤم في الثلاثة فإنّ ذلك يشير إلى ما قدّر الله على العبد، ويعني التئي

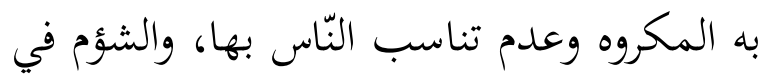
الثلاثة كلها جاء على معناه الخاص؛ المرأة شؤمها سوء الخلق وعدم ولودها؛ والدّار شؤمه ضيق وسوء جاره؛ والفرس شؤمه لم يغز عليه.
الأشياء المذكورة. وقيل يحمل الشؤم على قلة

$$
\text { الموافقة وسوء الطباع } 72 .
$$

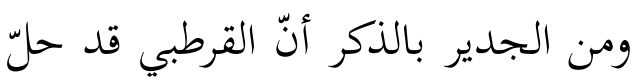

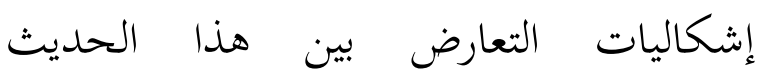

وأحاديث صحيحة أخرى بيان معنى قول النبّي كلا طيرة على من تطير ) فمعناه: من تطير بعد علمه

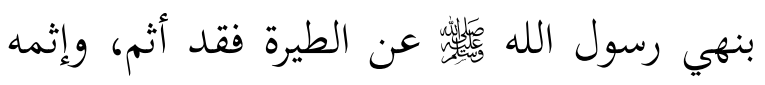
على تركه التّوكل على الله في تطيره، وزاد

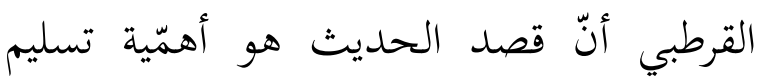

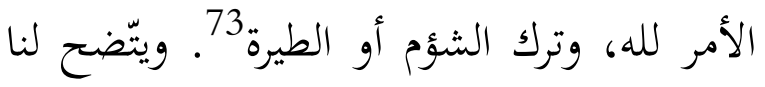

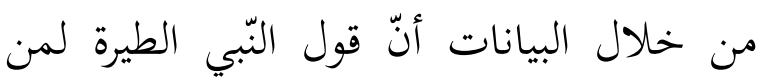
تطير جاء بمعنى الإثم لمن تطير، وليس إشارة

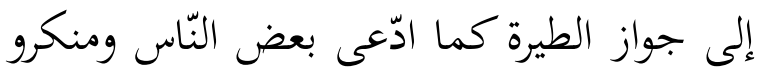
السنّة. ويتبيّن لنا من خلال كلام القرطبي أنّ

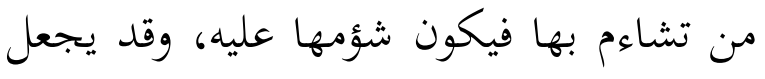
الله سبحانه وتعالى من تشاؤمه سبيًا لحلول المكروه، ولكنّ مِن الأحسن أن يترك التشاؤم

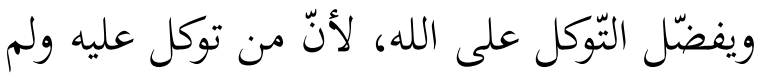

$$
\begin{aligned}
& 72 \text { انظر: الحافظ ابن حجر العسقلاني، فتح الباري شرح صحيح }
\end{aligned}
$$

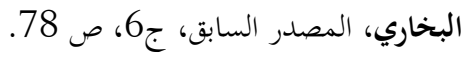

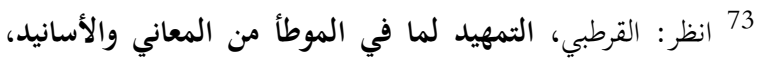

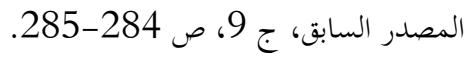


وبهذا، يتّخح لنا أنّ الإشكاليات

الخمسة التّي واجهها هذا الحديث، وهي: ظاهر الحديث متعارض بالعقيدة الإسلامية، تعارض الحديث بالأحاديث الصحيحة الأخرى، والادّعاء برفض عائشة عن هذائ الحديث، والحديث منسوخ بالآية والأحاديث الصحيحة الأخرى، والطعن في صحيح البخاري لحمل الحديث يشتمل على شرك

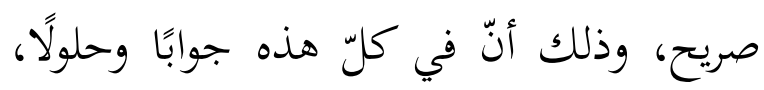
وهي: الشؤم المذكور لا يدخل ضمن الطيرة

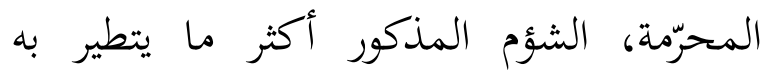
الإنسان لطول ملازمتها، الشؤم في الأمور الثّالثة على معناه الخاص، قول عائشة في أبي هريرة كذب من باب الغلظ والمبالغة في الغضب، ولا يثبت أن هذا الحديث منسوخ. وأخيرًا، نسأل الله أن يوفّقنا جميعًا في الدّنيا والآخرة. والله أعلم.
وهذا دليلٌ على أنّ الشؤم قد يكون لقوم دون قوم، لإنسان دون غيره، وذلك كلّه بمشيئة الله، وإنمّا يقع ذلك في هذه الأشياء التّي تلازم في غالب الأحوال، فإذا كان كذلك فاتركوها عنكم ولا تعذبوا أنفسكم بها. وإذا فهمنا الشؤم في الحديث مثلما ذكرناه سابقًا، لَمَا وجدنا أنّ الشؤم في الثلاثة هو من الشؤم الشركي المحرّم يبطل به الإيمان، ونرفض بذلك أيضًا الطعن في صحيح البخاري لحمل الحديث يشتمل على شرك صريح. وإضافةً إلى ذلك، إنّ رفض عائشة الحديث وقولها في أبي هريرة كذب ليس على وجه

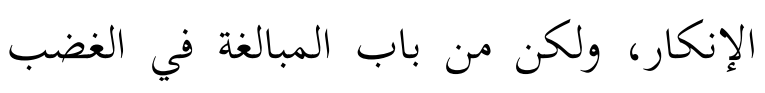
والظن ما ليس بصحيح. ويتبيّن لنا أيضًا من خلال البيانات والشروح أنّ هذا الحديث غير منسوخة بالآيات القرآنية ولا بالآحاديث

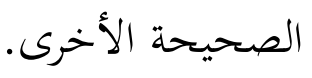

\section{References}

'Abd ar-Raḥmān bin Ḥasan. Fatḥ al-Majīd Sharḥ Kitāb at-Tawḥ̄id. N.ed. Riyaụ: Dār as-Salām. N.D.

'Alī aṣ-Șa'îdī al-Māliki. Ḥāshiyat 'alā Kifāyat aț-Ṭālib al-Rabbānī li Risālah ibn Abī Zayd alQayrawān̄i. Al-Hāmish: Kifāyat aṭ-Ṭālib al-Rabbānī li Risālah ibn Ab̄̄ Zayd alQayrawān̄̄ li ‘Alī Abī al-Ḥasan al-Māliki ash-Shāzlī. N.ed. Egypt: Sharikat Maktabat wa maṭba’at Muștāaā al-Bābī al-Khalbī wa Awlāduhu. 1938/1357. 
Nurul Badriyah binti Ali

Abū Daud Sulaymān bin al-Ash'ats al-Sijistāni, Sunan Abī Daud. Taḥqīq: Syu'aib al-Arnawūṭ, N.C: Dār al-Risālah al-'Ālamiyyah. $1^{\text {st }}$ ed. 2009/ 1430.

Abū Yaḥyā Zakariyya bin Muḥammad al-Anșārī. Tuḥfat al-Bari bi Sharḥ Ṣaḥ̄ḥ al-Bukhārī. Taḥqīq: Muḥammad Aḥmad ‘Abd al-‘Azīz Sālim. N.ed. Beirut: Dār Ibn Ḥazm. N.D.

Aḥmad bin Hanbal. Musnad Aḥmad bin Hanbal. Taḥqīq: Syu'aib al-Arnawūṭ. $1^{\text {st }}$ ed. N.C: Mu`assasat al-Risālah. 1996/1316.

Al-'Ain̄̄. 'Umdat al-Qāri' Sharḥ Șaḥ̄̄h al-Bukhārī. Taḥqīq: 'Abdullah Maḥmūd Muḥammad 'Umar. N.ed. Beirut: Dār al-Kutub al-'Ilmiyyah.

Al-Bukhạāī, Muḥammad bin Ismā'īl al-Bukhārī. Șaḥ̄h al-Bukhārī. Takhrīj wa Ḍabṭ: Ṣidqī al'Atțār. N.C: Dār al-Fikr. N.D.

Al-Būṣīīi. Ittiḥāf al-Ḥiyarah al-Mahrah bī Zawā'id al-'Ashrah. Taḥqīq: Abū 'Abd ar-Rahmān 'Ādil bin Sa'ad, Abū Isḥāq al-Sayyid Mạ̣mūd bin Ismā’̄il. N.ed. Riyaḍ: Maktabat alRushd.

Al-Dāraqțan̄. Al-'Ilal al-Wāridah fī al-Ahādith al-Nabawiyyah. Taḥqīq: Mạ̣fūẓ al-Raḥmān Zaynullah Al-Salafì. N.ed. N.C: N.P. N.D.

Al-Fāsī. Sharḥ Șaḥị̣ al-Bukhārī. Taḥqīq: 'Izat 'Atiyah, Musā Muḥammad 'Alī. N.ed. Cairo: Maṭba'ah Hasan.

Al-Ḥâfiz ibnu Hajar al-‘Asqalānī. Fatḥ al-Barī Sharḥ Șaḥ̄h al-Bukhārī. Tarqīm wa tabwīb al'Ahādith: al-Ustaz Muḥammad Fu’ād 'Abd al-Bāqī. Taḥqīq: 'Abd al-'Az̄̄z bin 'Abdullah bin Bāz. N.ed. Beirut: Dār al-Kutub al-'Ilmiyyah. N.D.

Al-Khaț̣ābī. I'lām as-Sunan fī Sharḥ Șaḥīh al-Bukhārī. N.ed. Beirut: Dār al-Kutub al-'Ilmiyyah. N.D.

Al-Kirmān̄̄. Șaḥ̄ḥ al-Bukhārī bi Sharḥ al-Kirmān̄̄. 2nd ed. Beirut: Dār Ihyā’ at-Turāth al-'Arab̄̄. $1981 / 1401$.

Al-Mannāwī. Al-Yawāqīt wa ad-Durar fī Sharḥ Nakhbat Ibn Ḥajar. Taḥqīq: al-Murtaḍā az-Zayn Aḥmad. N.ed. Riyāẹ: Maktabat ar-Rushd.

Al-Qaḍ̄i 'Iyyāọ al-Māliki. Mashāriq al-Anwār 'alā Șiḥhāḥ al-Āthār fī Sharḥ Gharīb al-Ḥadīth: alMuwaț̣a` wa al-Bukhāāī wa Muslim. Taḥqīq: Ibrahīm Shamsuddin. N.ed. Beirut: Dār alKutub al-Ilmiyyah. N.D.

Al-Qurțūbī. At-Tamhīd limā fī al-Muwaț̣a` min al-Ma’ānī wa al-Asānīd. Taḥqīq: Sa’̄̄d Aḥmad A’rāb. N.ed. N.C: Al-Maktabat al-Quddūsiyyah. N.D.

Al-Suyūṭ̂̀. Al-Tawshị̣ 'Alā al-Jamī’ al-Ṣaḥịh. Taḥqīq: 'Alā’ Ibrahīm al- ’Azharī. N.ed. Beirut: Dār al-Kutub al-'Ilmiyyah. N.D.

An-Nawāwī. Șaḥīḥ Muslim bī Sharḥ an-Nawāwī. N.ed. Egypt: al-Mațba’ah al-Mișriyyah bi alAzhar. N.D. 
Nurul Badriyah binti Ali

Hamdī 'Abdullah 'Abd al-'Az̄īm al-Ṣa'īdī. As-Sunnah an-Nabawiyyah Bayn Kayd al-'A'dā' wa Jahl al-Ad 'iyā’' 1st ed. Cairo: Maktabat Awlād al-Shaikh. 2007.

Kāmil 'Uwayḍah. Jāmi’ al-Fatāwā al-Mu'āṣirah min as-Salaf aṣ-Ṣāliḥ wa al-'Ulamā' alMu’āṣirīn. N.Ed. Silsilat Kitāb ibnu Luqmān. Mansourah: Dār al-Jazīrah li at-Tibā’ah. N.D.

Muslim bin al-Ḥajjāj. Șạ̣ịh Muslim. Taḥqīq: Naẓr bin Muḥammad al-Farābī Abū Qutaybah. N.ed. N.C: Dār Ṭaybah. 2006/ 1427.

Shamsuddīn al-Barmāwī. Al-Lāmi’ al-Ṣuḅ̣ bi Sharḥ al-Jāmi’ aṣ-Ṣaḥīh. Taḥqīq: Lajnah Mukhtașṣah min al-Muḥaqqiqīn bi Ishrāf Nur ad-Dīn aṭ-Ṭālib. N.ed. Qatar: Dār alNawādir. N.D.

Sulaymān bin 'Abdullah bin Muḥammad bin 'Abd al-Wahhāb. Taysīr al-'Azīz al-Ḥamīd fī Sharḥ Kitāb at-Tawḥ̄id. N.ed. N.C: 'Ālam al-Kutub. N.D.

Ṭāha Jayshī. Kitāb Ḍalālāt Munkirī as-Sunnah. 2nd ed. Cairo: Maṭba’at Rashwān. 2006/ 1427.

Wahbah az-Zuhaylī. Fatāwā Mu'āṣirah. 1st ed. Damascus: Dār al-Fikr,, Maktabat al-Asad. 2003/1424.

Website

http://bayanelislam.net/Suspicion.aspx?id=03-01-0152\# edn3 